\title{
INFLUÊNCIA DA PALHADA DE MILHETO NA \\ OCORRÊNCIA DE RAMULOSE (Colletotrichum gossypii var. \\ cephalosporioides Costa) NO ALGODOEIRO
}

DANIELA MOREIRA KUBIAK

Dissertação apresentada à Escola Superior de Agricultura "Luiz de Queiroz”, Universidade de São Paulo, para obtenção do título de Mestre em Agronomia, Área de Concentração: Fitotecnia.

P I R A C I C A B A

Estado de São Paulo - Brasil

Dezembro - 2003 


\title{
INFLUÊNCIA DA PALHADA DE MILHETO NA \\ OCORRÊNCIA DE RAMULOSE (Colletotrichum gossypii var. \\ cephalosporioides Costa) NO ALGODOEIRO
}

\author{
DANIELA MOREIRA KUBIAK \\ Engenheira Agrônoma
}

Orientador: Prof. Dr. EDERALDO JOSÉ CHIAVEGATO

Dissertação apresentada à Escola Superior de Agricultura "Luiz de Queiroz", Universidade de São Paulo, para obtenção do título de Mestre em Agronomia, Área de Concentração: Fitotecnia.

P I R A C I C A B A

Estado de São Paulo - Brasil

Dezembro - 2003 
Dados Internacionais de Catalogação na Publicação (CIP) DIVISÃO DE BIBLIOTECA E DOCUMENTAÇÃO - ESALQ/ USP

\author{
Kubiak, Daniela Moreira \\ Influência da palhada de milheto na ocorrência de remulose (Colletotrichum gossypiivar. \\ cephalosporioides Costa) no algodoeiro / Daniela Moreira Kubiak. - - Piracicaba, 2003. \\ 68 p. : il. \\ Dissertação (mestrado) - - Escola Superior de Agricultura Luiz de Queiroz, 2004. \\ Bibliografia. \\ 1. Algodão 2. Fungo fitopatogênico 3. Milheto 4. Palhada 5. Ramulose 6. Semeadura I. Título \\ CDD 633.51
}

"Permitida a cópia total ou parcial deste documento, desde que citada a fonte - $\mathrm{O}$ autor" 
À Deus, luz maior de minha vida e responsável por todas as coisas,

À minha mãe Dulce por me ajudar a existir,

Às minhas irmãs Marcela e Fernanda pela amizade e alegre convivência,

Às minhas queridas tias Alzira (in memorian) e Olga. Kubiak, por tornarem possivel esta realização

\section{DEDICO.}

Àquele, cujo a distância nunca diminuiu теи amor, meи pai Getulio, Ao pequeno Diego, minha maior realização neste período, e razão da minha vida, onde encontro em cada sorriso um incentivo à prosseguir, Ao amor desta vida e das que virão, meu esposo Guillermo, presença mais que necessária, imprescindivel em meus melhores e piores momentos. 


\section{AGRADECIMENTOS}

À Universidade de São Paulo e à Escola Superior de Agricultura "Luiz de Queiroz" (USP/ESALQ) pela oportunidade em realizar o curso e à infra-estrutura oferecida.

À Fundação Coordenação de Aperfeiçoamento de Pessoal de Nível Superior CAPES, pelo auxílio financeiro.

Ao Prof. Dr. Ederaldo José Chiavegato pela orientação científica, dedicação e amizade, a quem terei sempre como mestre, imposição do respeito, e ao mesmo tempo um porto seguro às duvidas e inquietações da vida acadêmica.

Aos Professores: Gil Miguel de Souza Câmara, Marcos Silveira Bernardes, José Dias Costa, Durval Dourado Neto, Geraldo Aparecido D’ario, Pedro Jacob Crhistofoletti, pela atenção, esclarecimento de dúvidas, apoio e amizade.

Ao Prof. Dr. Antonio Roberto Pereira, por ser sempre solícito e amigo.

Ao Prof. Dr. Paulo César Sentelhas, pela colaboração e boa vontade em ceder os equipamentos para avaliação das variáveis meteorológicas.

Ao Engenheiro Agrônomo José Eduardo B. Monteiro, pela montagem dos equipamentos no ensaio experimental.

Ao Engenheiro Agrônomo Edson Roberto Teramoto, responsável pela área experimental agrícola do Departamento de Produção Vegetal - Agricultura USP/ESALQ.

Aos funcionários do Departamento de Produção Vegetal - Agricultura - USP/ESALQ Adilson Aparecido Dias, Adilson de Jesus Teixeira, Ananias Ferreira Sousa, Antonio Pereira de Andrade, César Renato Galvão Desiderio, Claudinei Martins Valério, Claúdio do Espírito Santo, Daniel Luiz Theodoro, Edson Ademir de Moraes, Jair Vitória Artur, 
João Rodrigues, José dos Reis Lopes, José Soares de Almeida, Laerte Tiberio, Marcelo Valente Batista, Osmair Roberto Neves, Osvaldo de Jesus Pelissari, Rodrigo Camargo Campos e Wilson Góes da Silva pelo auxílio nas atividades experimentais.

Ao Sr. Celestino Alves Ferreira, Maria Aparecida Soledade e Silvia Borghesi pelo apoio técnico administrativo.

Ao Engenheiro Agrônomo Luis Fernando S. Marchiori, responsável administrativo Fazenda Areão, local da experimentação, pela infra-estrutura e apoio nas atividades de campo, e aos funcionários Celso José Negretti, Derli Cândido Pena, José Luiz Mandro (Zé) e Valdinei Ribeiro de Camargo (Pirarha).

À técnica do Laboratório de Análise de Sementes do Departamento de Produção Vegetal USP/ESALQ, Helena Maria C. P. Chamma pela orientação e colaboração nos testes de germinação de sementes.

A Maria Angelica Pizzinatto, responsável pelo pelo Centro de Pesquisa e Fitossanidade da Agência Paulista de Tecnologias dos Agronegócios (Instituto Agronômico de Campinas, centro experimental central) pela cessão do inóculo utilizado no experimento.

Às bibliotecárias Eliana Maria Garcia e Sílvia Maria Zinsly da USP/ESALQ pela revisão desta dissertação.

Ao Engenheiro Agrônomo e amigo Fábio Lima de Almeida Melo (Touché), pelo companheirismo enquanto estagiário e posteriormente como mestrando e pela caminhada harmoniosa e descontraída até o dia de hoje.

Á Engenheira Agrônoma Ariana Vieira e Silva, pela amizade e participação nas avaliações de campo e contribuição na confecção deste trabalho.

Aos estagiários do Grupo de Experimentação na Cultura do Algodão (GEALG), Pedro P. Avila de Aguiar (Fidukão), Rogério Costa Rodrigues (Brakiária), Diego T. Suhet (Suéter) e Otávio D. Giunti (Bombril) pelo auxílio nas atividades de campo.

Aos novos amigos adquiridos neste período, companheiros de disciplinas e seminários, especialmente ao Engenheiro Agrônomo Hector,Alonso San Martin Matheis que se revelou um amigo. 
Ao meu esposo Guillermo Rafael Salvatierra, por todo amor, apoio, incentivo, presteza e dedicação, e um dos principais responsáveis por ser este período do mestrado um tempo especial de minha vida.

Ao meu amado filho Diego Rafael Salvatierra Kubiak, por ser a fonte de minhas forças, e porque, sendo ainda tão pequeno me dá tantas lições de vida, e que também fez deste período do mestrado um alicerce para a vida toda.

Ao meu querido pai Getulio Kubiak, meu maior orgulho, pela lição de vida, vontade, amor, e que apesar da distância, nunca deixou de ser pai e estar torcendo por minhas realizações, fazendo-as dele também.

À querida madrinha Olga Kubiak, pelo incentivo e interesse constantes nos meus projetos, tanto acadêmicos como de vida e aos meus avós paternos Bronislau e Sophia Kubiak e avó materna Maria de Lourdes G. Moreira pelo amor e apoio. Agradeço a Deus por tê-los vivos ao meu lado.

À minha mãe Dulce Maria Moreira Kubiak e irmã Fernanda Moreira Kubiak por disporem de seu tempo para cuidarem com tanto carinho do meu Diego enquanto realizava este trabalho.

Á minha irmã Marcela Moreira Kubiak pela ajuda com o inglês.

À todas as pessoas que direta ou indiretamente auxiliaram na realização deste trabalho.

Já dizia Aristóteles (384-322 a.c.) que o segredo de fazer cada coisa da vida ficar bem feita é o equilíbrio em tudo o que fazemos.

Não devemos ser covardes, nem audaciosos, mas corajosos, Não devemos ser avarentos, nem extravagantes, mas generosos, Não devemos ser geniais nem ignorantes, mas estudiosos. 
À Guillermo Rafael, minha homenagem

De tudo, ao meu amor serei atento

Antes, e com tal zelo, e sempre, e tanto

Que mesmo em face do maior encanto

Dele se encante mais meu pensamento.

Quero vive-lo em cada vão momento

E em seu louvor hei de espalhar meu canto

E rir meu riso e derramar meu pranto

Ao seu pesar ou o seu contentamento

E assim, quando mais tarde me procure

Quem sabe a morte, angústia de quem vive

Quem sabe a solidão, fim de quem ama

Eu possa me dizer do amor (que tive):

Que não seja imortal, posto que é chama

Mas que seja infinito enquanto dure.

Soneto da fidelidade, de Vinícius de Moraes 


\section{SUMÁRIO}

Página

LISTA DE TABELAS................................................................ $\mathrm{x}$

LISTA DE FIGURAS.................................................................... xii

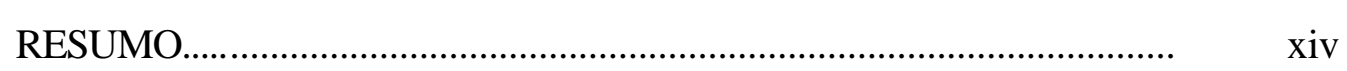

SUMMARY ........................................................................... Xvi

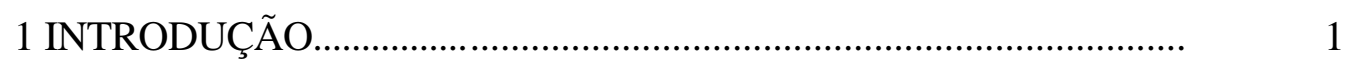

2 REVISÃO DE LITERATURA............................................................... 4

2.1 Algodoeiro e sistemas de produção........................................................

2.2 Doenças do algodoeiro em Plantio Direto e sistemas conservacionistas. 9

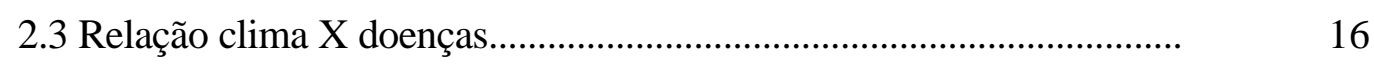

2.4 Influência da palhada no microclima e ocorrência de doenças................ 17

3 MATERIAL E MÉTODOS.................................................................. 21

3.1 Local e período de condução................................................................. 21

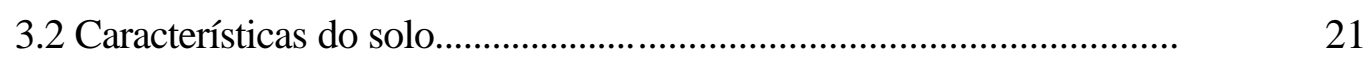

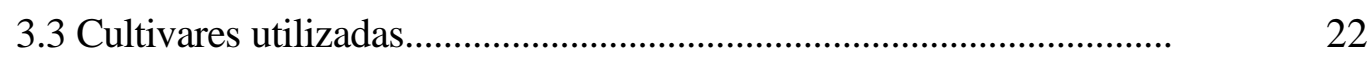

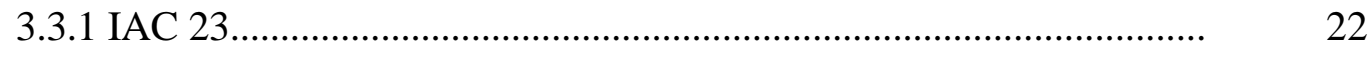

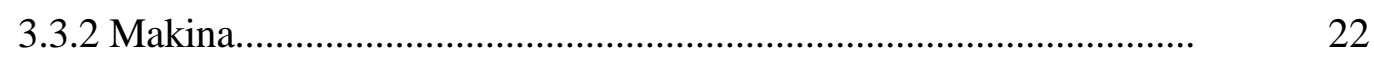

3.4 Monitoramento dos elementos meteorológicos...................................... 23

3.5 Delineamento experimental ............................................................ 24

3.6 Implantação e condução do experimento................................................ 25

3.6.1 Período anterior à semeadura do algodoeiro....................................... 25

3.6.2 Semeadura do algodoeiro e condução do experimento........................... 29 
3.6.3 Inoculação do patógeno nos tratamentos................................................ 31

3.7 Variáveis analisadas........................................................................... 33

3.7.1 Ramulose nos sistemas de semeadura e evolução da doença nos

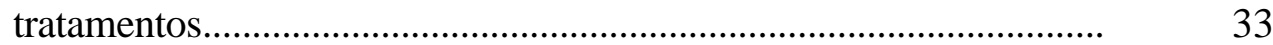

3.7.2 Produção de algodão em caroço e produtividade.................................. . $\quad 34$

3.7.2.1 Caracteres agronômicos de laboratório................................................ . . 34

3.7.3 Características Tecnológicas das Fibras................................................ 34

4 RESULTADOS E DISCUSSÃO.......................................................... 36

4.1 Ramulose nos sistemas de semeadura e evolução da doença nos tratamentos 36

4.1.1 Ramulose nos sistemas de semeadura................................................ 36

4.1.2 Evolução da Ramulose nos tratamentos.................................................. 42

4.2 Análise das condições meteorológicas.................................................. 47

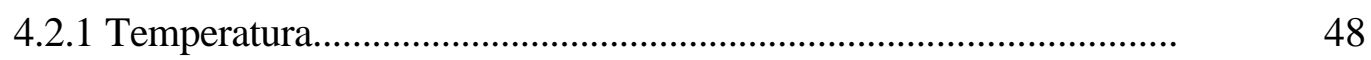

4.2.2 Umidade Relativa do Ar................................................................ 50

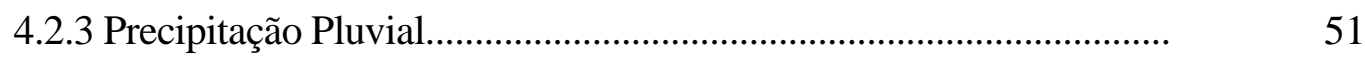

4.2.4 Radiação Solar............................................................................. 52

4.2.5 Velocidade do Vento............................................................................. 53

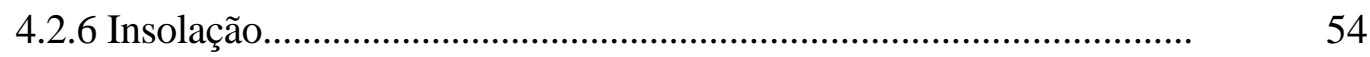

4.3 Produção e produtividade.................................................................. 55

4.3.1 Caracteres agronômicos de laboratório............................................... 57

4.4 Características tecnológicas das fibras................................................... 58

5 CONCLUSÕES............................................................................

REFERÊNCIAS BIBLIOGRÁFICAS....................................................... 60 


\section{LISTA DE TABELAS}

Página

1 Resultados da análise química do solo para macronutrientes da área experimental, na profundidade de 0-20 cm. Piracicaba, 2001.

2 Resultados da análise química do solo para micronutrientes da área experimental, na profundidade de $0-20 \mathrm{~cm}$. Piracicaba-SP

3 Dados médios mensais dos elementos meteorológicos do período de experimentação, de 1917 à 2000, em Piracicaba SP

4 Tratamentos utilizados. Ano agrícola 2002/03. Piracicaba, SP...........

5 Peso em gramas das amostras coletadas de milheto secas em estufa...

6 Condições meteorológicas no período de dois meses anteriores à inoculação Ano Agrícola 2002/03. Piracicaba, SP...

7 Condições meteorológicas no dia da inoculação. 202/03.Piracicaba, SP

8 Escala de notas para avaliação da Ramulose do algodoeiro

9 Datas das avaliações realizadas nas parcelas experimentais e correlação com a fase fenológica. Ano agrícola 2002/03. Piracicaba, SP.

10 Médias das notas atribuídas à severidade da Ramulose nas plantas para todos os tratamentos. Ano agrícola 2002/03. Piracicaba, SP

11 Condições meteorológicas dos três meses seguintes àinoculação Ano agrícola 2002/03. Piracicaba, SP.

12 Quadrado médio (Q.M.), F da análise de variância (F) e coeficiente de variação dos resíduos (C.V.) referentes à produção de algodão em 
caroço $(\mathrm{kg})$.

13 Médias de produção de algodão em caroço e da produtividade, em todos os tratamentos. Ano agrícola 2002/03. Piracicaba, SP.

14 Média dos tratamentos para os caracteres agronômicos de laboratório.

15 Média dos tratamentos para as características tecnológicas das fibras. 


\section{LISTA DE FIGURAS}

Página

1 Esquema de subparcela experimental. Ano agrícola

2002/03. Piracicaba, SP

2 Detalhe de faixa com milheto em desenvolvimento e aspersores.

Ano agrícola 2002/03, Piracicaba, SP

3 Plantas de milheto 7 dias após a dessecação. Ano agrícola 2002/03.

Piracicaba, SP

4A Detalhe de emergência de plântulas de algodão em semeadura sobre palha. Ano agrícola 2002/03. Piracicaba, SP.

4B Emergência de plântulas na semeadura convencional. Ano agrícola 2002/03. Piracicaba, SP.

5 Comparação estatística das médias de notas para a cultivar resistente IAC 23 em relação ao sistema de semeadura em todas as avaliações

6 Comparação estatística das médias de notas para a cultivar suscetível (Makina) em relação ao sistema de semeadura, em todas as avaliações......

7A Evolução da severidade da Ramulose nos tratamentos em todas as avaliações.

7B Precipitação (mm) e umidade relativa (\%) no período de condução. 43

7C Temperaturas máxima, média e mínima no período de condução.

8 Evolução da Ramulose para as cultivares resistente (IAC 23) e suscetível (Makina).

9 Comparação de medidas de temperatura máxima do ano agrícola 
2003/03 e histórico de 10 anos, para o local de experimentação.............

10 Comparação de medidas de temperatura mínima do ano agrícola

2003/03 e histórico de 10 anos, para o local de experimentação

11 Comparação de medidas de temperatura média $\left({ }^{\circ} \mathrm{C}\right)$ do ano agrícola 2003/03 e histórico de 10 anos, para o local de experimentação.

12 Comparação de medidas de Umidade relativa média (\%) do ano agrícola 2003/03 e histórico de 10 anos, para o local de experimentação.

13 Comparação de medidas de Precipitação pluvial (mm) do ano agrícola 2003/03 e histórico de 10 anos, para o local de experimentação.................

14 Comparação de medidas de Radiação Solar (cal $/ \mathrm{cm}^{2} /$ dia) do ano agrícola 2003/03 e histórico de 10 anos, para o local de experimentação.................

15 Comparação de medidas de Velocidade média do vento $(\mathrm{Km} / \mathrm{h})$ do ano agrícola 2003/03 e histórico de 10 anos, para o local de experimentação.

16 Comparação de medidas de insolação média (h/d) do ano agrícola 2003/03 e histórico de 10 anos, para o local de experimentação. 


\title{
INFLUÊNCIA DA PALHADA DE MILHETO NA OCORRÊNCIA DE RAMULOSE (Colletotrichum gossypii var cephalosporioides Costa) NO ALGODOEIRO
}

\author{
Autora: DANIELA MOREIRA KUBIAK \\ Orientador: Prof. Dr. EDERALDO JOSÉ CHIAVEGATO
}

\section{RESUMO}

Foi realizado um estudo na cultura do algodoeiro (Gossypium hirsutum L. var latifolium Hutch), no ano agrícola 2002/2003, na Fazenda Areão, unidade experimental da Escola Superior de Agricultura "Luiz de Queiroz", USP/ESALQ, localizada no município de Piracicaba, SP, com o objetivo de avaliar o comportamento e evolução da Ramulose do algodoeiro, doença causada pelo fungo Colletotrichum gossypii var cephalosporioides Costa em sistema de semeadura com e sem palha de milheto (Pennisetum glaucum L.), nas cultivares IAC 23 (resistente à Ramulose) e Makina (suscetível à Ramulose). Foram avaliadas também as interações entre o sistema de semeadura com e sem palha na produção de algodão em caroço, produtividade da cultura, caracteres agronômicos de laboratório e características tecnológicas das fibras. O delineamento experimental adotado foi o de parcelas subdivididas (split-plot), utilizando-se 4 blocos alternados entre semeadura convencional e semeadura sobre a palhada de milheto (parcelas), cada um com 8 subparcelas, totalizando 32 subparcelas. Aos 34 dias após a emergência (DAE) o patógeno foi inoculado artificialmente com a 
suspensão de inóculo pulverizada no terço superior das plantas através de equipamento de $\mathrm{Co}_{2}$. A doença foi avaliada através de escala de notas (1 a 5), e os resultados permitiram concluir que a quando as condições meteorológicas são favoráveis ao patógeno, a presença da palha na superfície do solo influencia negativamente no crescimento da doença na cultivar suscetível. A cultivar resistente IAC 23 retoma o crescimento vegetativo quando as condições meteorológicas são desfavoráveis ao patógeno e na cultivar Makina, sob condições favoráveis, a doença cresce, mas continua estável quando as condições se tornam desfavoráveis ao patógeno. A palha não afetou a produção de algodão em caroço, a produtividade, os caracteres agronômicos de laboratório e nem as características tecnológicas das fibras. Quando as condições meteorológicas são típicas, o Sistema de Plantio Direto desfavorece o desenvolvimento da doença, podendo ocorrer o inverso quando as condições meteorológicas forem atípicas 


\title{
INFLUENCE OF THE COVER RESIDUE IN THE RAMULOSIS OCCURENCE, DISEASE CAUSED BY FUNGUS Colletotrichum gossypii var. cephalosporioides Costa IN THE COTTON PLANT
}

\author{
Author: DANIELA MOREIRA KUBIAK \\ Adviser: Prof. Dr. EDERALDO JOSÉ CHIAVEGATO
}

\section{SUMMARY}

A study in the culture of cotton plant (Gossypium hirsutum L. var latifolium Hutch), was conducted in the agricultural year of 2002/2003, at the experimental unity of Escola Superior de Agricultura "Luiz de Queiroz", USP/Esalq, located in the city of Piracicaba, SP, with the objective to evaluate the behavior and evolution of the Ramulosis of the cotton plant, disease caused by the fungus Colletotrichum gossypii var cephalosporioides Costa in the system of sowing with and without cover residue (straw), when cultivar IAC 23 (resistant to Ramulosis) and Makina (susceptible to Ramulosis). It has also been evaluated the interactions between the the system of sowing with and without the cover residues (straw) in the production of cotton and yield of the culture, agronomics characters of laboratory,and the characteristics of the fibers. The experimental delineation adopted split-splot, using 4 blocks alternated between conventional sowing on the cover residue (parcels), each one with 8 suparcels, totalizing 32 sub parcels. To the 34 days after the emergency (DAE) the fungus was inoculated artificially in the plants. The disease was evaluated through grading scales (1 to 5), and the results allowed to conclude that he presence of the cover residue (straw) in the surface of the soil influence negatively to the growth of the disease only when the 
meteorological conditions are favorable to the development of the pathogenic, and depending on the used cultivar. When cultivar resistant IAC 23 it presented greater sensitivity to meteorological conditions retaking the vegetative development with healthy sprouts, when the meteorological conditions had been unfavorable to the growth of the disease, while that in cultivar susceptible Makina the disease if kept steady when the conditions had been unfavorable. The cover residue (straw) did not affect the production of the cotton, neither the yield, the agronomic characters of laboratory, or the characteristics of the fibers. 


\section{INTRODUÇÃO}

A cultura do algodoeiro vem se tornando, dentre as grandes culturas, cada vez mais importante no cenário agrícola brasileiro nos últimos anos. Ocorreram modificações, tanto em relação às regiões de importância, como na tecnologia empregada na sua produção. As áreas de produção, antes concentradas na região sul e sudeste, caracterizadas por pequenas áreas de produção e sistemas menos tecnificados, hoje ocupam regiões do Brasil central, região da retomada da recuperação da cultura algodoeira.

A expansão da cultura nestas regiões permitiu grande aumento das ofertas dos produtos no mercado interno, e muitas são as características que fazem do cerrado brasileiro uma região altamente viável, onde há pouco mais de 10 anos, já se esperava ser uma nova fronteira agrícola, com potencial para ser explorada a médio e a longo prazos, o que hoje é uma realidade definida, com resultados crescentes de produção e produtividade a cada safra.

Dentre as características que fazem desta uma região de importância agrícola, estão as grandes áreas planas que possibilitam os grandes módulos de produção, total mecanização das culturas e uso intensivo de insumos agrícolas.

Diante desses fatores, a cultura algodoeira têm alcançado altas produtividades, onde além do êxito no mercado interno, também teve aumento significativo das exportações, o que levou os grandes produtores a entenderem que o mercado de algodão tem agora um novo perfil, exigente em qualidade, com políticas governamentais e mercados específicos, o que justifica a necessidade da utilização de novas técnicas que possibilitem a melhoria da qualidade do produto, permitindo aumento de produção e produtividade. 
Nesta safra de 2002/2003 estima-se que a área plantada com algodão no Brasil tenha sido de 736, 7 mil hectares, e a produtividade ao redor de $2960 \mathrm{~kg} / \mathrm{ha}$. (Anuário Brasileiro do Algodão, 2003).

Nestas regiões produtoras, a soja sempre esteve como principal cultura, e por causa dos sistemas de monocultura, com preparo convencional do solo, que ao longo dos anos vêm produzindo degradação química, erosão e aumento da incidência de doenças e pragas, este sistema de produção começou a entrar em decadência, e têm sido difundidas entre as regiões produtoras a utilização de sistemas alternativos como o Sistema de Plantio Direto (SPD) e outros sistemas conservacionistas, que têm como base principal a rotação de culturas, o menor revolvimento do solo e a manutenção da sua cobertura o ano todo.

Neste ínterim, o algodão entrou como opção rentável de culturas na rotação, e foi se destacando pelo aumento de produção a cada ano, e estima-se que na safra 2002/2003 a produção total do Brasil tenha sido em torno de 1351,4 mil toneladas de algodão em caroço. (Anuário Brasileiro do Algodão, 2003).

O cultivo do algodoeiro, em larga escala, quando em monocultura, é uma prática exigente em termos de nutrição do solo, manejo e ambiente, considerando as condições favoráveis ao seu desenvolvimento. Práticas de preparo do solo, como arações, gradagens, exposição prolongada provocada pela lenta cobertura no início do desenvolvimento vegetativo, resultam num desgaste muito grande do ponto de vista físico, químico e biológico, criando problemas de erosão, compactação, comprometimento da fertilidade, umidade, e incidência de pragas e doenças. (Yamaoka, 1999). Em vista disso, a utilização do algodoeiro como uma das culturas no sistema de rotação em Plantio Direto é uma alternativa para minimizar esses problemas.

O plantio direto do algodoeiro, especificamente, apresenta algumas dificuldades, sendo que um dos problemas comumente encontrados quando se utililiza este sistema de produção e outras práticas conservacionistas na cultura do algodoeiro, e já constatados por diversos autores (Kaufman et al., 1995; Young, 1995; Sumner, 1997), é o agravamento das doenças fúngicas que ocorrem no período inicial do desenvolvimento da cultura (Damping off ou tombamento de plântulas), causadas por 
diversos patógenos, devido à viabilização do desenvolvimento destes pela permanência e sobrevivência do patógeno na palhada, principalmente porque a palhada causa a modificação do microclima da cultura, pela diminuição da amplitude térmica do solo, entre outros efeitos.

São evidentes os problemas em relação à fungos saprofíticos causadores de tombamento de plântulas, no entanto, uma das principais doenças do algodoeiro atualmente é a Ramulose, causada pelo patógeno Colletotrichum gossypii var cephalosporioides Costa, disseminado principalmente através de sementes, havendo a possibilidade de sobreviver em restos de cultura e ser veiculado no ano seguinte.

Pouco se estudou em relação à potencialidade desta doença em sistemas conservacionistas com utilização de resíduos de culturas na superfície, quais os possíveis efeitos que a mudança do microclima no interior do dossel poderá causar no seu desenvolvimento, qual a real periculosidade da coexistência do patógeno e os novos sistemas de produção em expansão, nas mais importantes regiões produtoras.

Visualizando os problemas decorrentes da Ramulose do algodoeiro, sabendo-se que o SPD e outras práticas conservacionistas vêm sendo cada vez mais adotadas, e que a utilização de técnicas culturais que modifiquem o microclima no interior do dossel podem pré-dispor a planta ao ataque de patógenos e desenvolvimento de doenças, o objetivo do presente estudo foi verificar a evolução da Ramulose em cultivar suscetível (IAC 23) e cultivar resistente (Makina) comparativamente em semeadura convencional e semeadura sobre palhada,e as possíveis interferências dos sistemas de semeadura na produção e características das fibras. 


\section{REVISÃO DE LITERATURA}

\subsection{Algodoeiro e sistemas de produção}

O algododoeiro (Gossypium hirsutum L. var latifolium Hutch), é um fitossistema dos mais complexos, por se tratar de uma planta de hábito de crescimento indeterminado e frutificação em ramos simpodiais (Oosterhuis, 1999), possuindo grande complexidade morfológica.

As espécies de ciclo anual, chamadas de "upland" possuem estrutura organográfica com dois tipos de ramificação (ramos frutíferos e ramos vegetativos), dois tipos de macrófilos (frutíferos e vegetativos), entre outras características morfológicas peculiares (Beltrão \& Souza, 1999), que fazem com que esta planta tenha elevada plasticidade fenotípica, se adaptando à diversos ambientes.

Medeiros (2003) relata que quando os europeus chegaram ao Brasil, os índios já cultivavam esta malvácea, transformando fios em tecidos, e utilizando seu caroço para alimentação e fins medicinais. No século XI, seu cultivo se espalhou pelos estados da Bahia, Pernambuco, e Maranhão no século XVIII, e mais adiante, se expandindo pelo Nordeste, que se tornou grande região produtora no Brasil.

O mesmo autor afirma que o eixo da cultura esteve sempre em deslocamento, chegando no Sul do Brasil no século XX, onde por muitos anos a pesquisa esteve concentrada. Atualmente a produção do algodoeiro está concentrada na região Centrooeste do Brasil, nos estados de Mato Grosso, Goiás, Mato Grosso do Sul e Bahia, sendo que a contribuição de cada estado na produção nacional é para cada estado é 56, 12, 7 , 
6\% respectivamente. Os Estados de São Paulo e Paraná, tradicionais na produção de algodão contam com 6,5 e 6,3\% na produção total do Brasil.

A forma de manejo, que perdura até hoje na maioria das áreas cultivadas, é o preparo convencional do solo, caracterizado por arações e gradagens, incluindo outras operações que promovem o intenso revolvimento do solo, causando grandes perdas e o seu empobrecimento.

O tipo de manejo do solo, a monocultura e a baixa produção de biomassa do algodoeiro (2,5 t de matéria seca por hectare) associados à rápida mineralização desta caracterizou o sistema de produção vigente como insustentável, pois, gradativamente estabelecia o balanço negativo do carbono, causando a freqüente migração da cultura para novas áreas, sendo que hoje, as principais áreas produtoras se encontram na região dos cerrados, principalmente devido à predominância de relevos planos, o que possibilita total mecanização e altas escalas de produção. Nesta região, parte das áreas já estão modificando seus sistemas de produção, fazendo a transição do sistema de produção convencional para o sistema de plantio direto (Medeiros, 2003), ou mesmo diminuindo o número de operações que promovem o revolvimento do solo, caracterizando o sistema como conservacionista.

Gassen \& Gassen (1996), definem a expressão "plantio direto" como a prática de semeadura ou de cultivo de plantas sem preparo físico do solo, mantendo a palha da cultura anterior na superfície. Posteriormente o Sistema de Plantio Direto (SPD), foi definido por Hernani \& Salton (1998) como um programa de rotação de culturas caracterizado pelo cultivo em terreno coberto por palha e/ou plantas em desenvolvimento e em ausência de preparo do solo, por tempo indeterminado.

A utilização da cobertura morta sobre a superfície, é um dos fatores que determinam o sucesso do sistema, protegendo os agregados do solo contra erosão, redução da evaporação, do escorrimento superficial, aumento da infiltração e do armazenamento de água no perfil do solo.

Porém, o SPD, quando não adotado por algum motivo, procura-se fazer ao menos algum tipo de preparo conservacionista, o que vem sendo muito utilizado em 
áreas de produção do Mato Grosso, como plantio na palha e diminuição do número de operações e trânsito de implementos, de forma que o sistema de produção apresenta algumas nuances desde o preparo convencional até o SPD, passando por sistemas de preparo reduzido, cultivo mínimo entre outros, sendo denominados de preparo conservacionista.

Fowler \& Rockstrom (2001) fazem uma breve conceituação de preparo conservacionista como sendo um termo genérico para os sistemas de manejo de solo que visam a conservação dos recursos naturais, e afirmam que manter pelo menos $30 \%$ da superfície do solo coberta por resíduos é essencial para conservar o solo e a água.

As práticas convencionais de preparo do solo utilizadas no algodoeiro, através de arações e gradagens, de forma contínua, e aliada a uma exposição prolongada do solo, provocada por lenta cobertura (aproximadamente 90 dias), devido ao desenvolvimento inicial lento da cultura, resultam num desgaste significativo do solo, do ponto de vista físico, químico e biológico, tais como comprometimento da atividade microbiológica, compactação, umidade, pragas e doenças (Yamaoka, 1999).

Dos 5,2 bilhões de hectares de cultivo de sequeiro no mundo, para produção de culturas, $70 \%$ estão degradadas e 24 bilhões de toneladas de solo são perdidos anualmente. ( Fowler \& Rockstrom, 2001). Os mesmos autores concordam que a chave para este problema na agricultura tropical é combater o declínio da fertilidade do solo, resultado da erosão associada ao preparo convencional.

Reeves (2000), salienta que o sistema de plantio convencional proporciona condições mais frias e mais úmidas, há menor incidência de doenças de plântula, menor sensibilidade alelopática pela não utilização do adubos verdes, sendo assim, a utilização do SPD diminui a amplitude térmica do solo, havendo potencialidade para ocorrência de doenças e de efeito alelopático pela utilização de adubos verdes não adequados, menor compactação do solo e menor revolvimento, significando diminuição de perdas de solo devido à erosão, entre outros.

Kladivko et al. (2001) afirmam que os sistemas de preparo do solo afetam as características químicas, físicas e biológicas do solo, mudando o conteúdo de água e a 
temperatura e aeração, e que essas mudanças no ambiente do solo modificam o suprimento de alimento dos organismos afetando os diferentes grupos, sendo necessário entender o impacto do manejo no complexo das interações de todos os níveis de comunidades e em adição a isto se faz necessário entender a ação dos organismos do solo, pois estes contribuem para a melhoria da estrutura, ciclagem de nutrientes e decomposição da matéria orgânica

Assim, o sistema de plantio direto seria uma alternativa para sanar os problemas advindos da utilização contínua do sistema de plantio convencional, porém, várias dificuldades foram surgindo com a gradativa utilização do SPD pelos cotonicultores, aos poucos, sendo solucionadas ou minimizadas, numa tentativa constante de potencializar a sua utilização, tornando-se assim uma alternativa adequada às condições tropicais, no que diz respeito ao manejo do solo. (Yamaoka, 1999)

Em histórico apresentado por Yamaoka (1999), as primeiras citações sobre a necessidade de uma agricultura com sistemas conservacionistas foram em 1961, e a partir daí, foram sendo desenvolvidos outros trabalhos nessa linha de pesquisa, principalmente no estado do Paraná, onde foram sendo criados acordos, fundações e a Federação Brasileira de Plantio Direto na Palha, em 1992, que congrega todas as organizações que trabalham em pról do Plantio direto.

Estudos realizados por Smart et al. (1995), revelaram que menos que $10 \%$ de todo o algodão produzido pelos EUA utilizavam sistemas conservacionistas, preparo reduzido e plantio direto, no entanto, dados mais atuais de Reeves (2000), revelam que na safra de 2000/01, apenas $13 \%$ de toda a área plantada com algodão nos EUA tinham algum tipo de preparo conservacionista, onde algumas regiões têm resistido à mudança no sistema de produção, principalmente naquelas onde existe alto potencial de produção, e acesso à irrigação, há pouco incentivo para reduzir o uso de insumos e fazer preparo conservacionista.

O mesmo autor coloca que dentre os principais problemas na utilização do plantio direto e conservacionista do algodoeiro estão a dificuldade de uniformidade de germinação para obter uma população de plantas em sistemas conservacionistas, 
principalmente pelas condições do solo mais frias e mais úmidas (solos americanos) comparado ao preparo convencional; sensibilidade do algodão à doenças, sensibilidade pela atividade alelopática associadas com adubos verdes, entre outras. Fortin, já constatava, em 1993, trabalhando com a cultura do milho, que sistemas de plantio direto podem criar condições desiguais de emergência de plântulas e estand inicial, bem como proporcionar crescimento inicial mais lento.

No Brasil, a área cultivada sob sistema de plantio direto se manteve estável até meados dos anos 80, e partir daí tem tido um crescimento contínuo, com salto significativo a partir da década de 90. Dados de 1999 mostram uma área cultivada de 9,1 milhões de hectares em sistema de plantio direto no Brasil, sendo distribuídos da seguinte maneira: Cerrados (3,0); Rio Grande do Sul (2,8); Paraná (2,37); Mato Grosso do Sul $(0,52)$ e outros $(0,4)$. (Yamaoka, 1999). Dos estados acima, o que vem se destacando pela utilização de sistemas conservacionistas na cultura do algodoeiro e com aumento significativo da área é o Mato Grosso do Sul, com mais de 11.200 ha., sendo que a quase totalidade utiliza o milheto como cobertura para formação de palhada.

Há muitas opções de culturas para utilização como adubo verde e formação de palhada para a cultura subsequente do algodão, o que cabe fazer um estudo das condições edafoclimáticas do local (Deuber, 1999), e das características de cada espécie, permitindo assim analisar as possibilidades e espécies adequadas a este fim.

A utilização do milheto (Pennisetum glaucum) como cobertura para formação de palhada, para plantio subsequente do algodoeiro está sendo muito bem aceita em diversas regiões do Brasil, principalmente no Mato Grosso do Sul, utilizado na primavera, com semeadura desde o início de setembro, pois é uma espécie que, aos 45 a 50 dias após a semeadura proporciona uma excelente cobertura do solo (90\%), e quantidade de matéria seca de 8 a 10 tha $^{-1}$, o que é extremamente benéfico não só nas condições do Mato Grosso do Sul, mas para os solos tropicais, de maneira geral, que sofrem com a ação das altas temperaturas e umidade, o que aumenta a taxa de decomposição da matéria orgânica da superfície do solo. 
Cabe salientar que as condições macroclimáticas encontradas nas regiões de produção americanas, por serem totalmente distintas das que encontramos no Brasil, pois na maioria das regiões, no período do inverno, o solo fica coberto por gelo, e na estação de cultivo, deseja-se que o solo tenha um certo aquecimento, e para isso o solo é revolvido, indo contra os princípios básicos para a utilização do SPD, assim, o sistema é denominado conservacionista.

\subsection{Doenças do algodoeiro em Plantio Direto e sistemas conservacionistas}

Um dos principais entraves à utilização do SPD, no caso do algodoeiro é o agravamento de doenças de plântulas, o que concorda com resultados de trabalhos realizados por Kaufman et al. (1995); Young (1995) e Sumner (1997), que afirmam que há agravamento de doenças de plântulas quando é utilizado o sistema de plantio direto, preparo reduzido ou conservacionista, principalmente damping-off ou tombamento de plântulas, cujos sintomas podem ser observados logo após a emergência das plântulas, nas folhas cotiledonares e primárias, que apresentam lesões de formato irregular e coloração pardo escura, que também aparecem no caule, que quando circundam todo o caule, ocorre o tombamento e morte da plântula (Cia \& Fuzzato, 1999), o que pode ser minimizado pela utilização de rotação de culturas.

O Tombamento de Plântulas é causado por um complexo de microorganismos fúngicos, e no Brasil os de ocorrência mais comum são Colletotrichum gossypii South, Rhyzoctonia solani Kuehn e Fusarium spp, ocorrendo em condições de alta umidade no solo.(Gridi-Papp et al., 1992).

Brown e McCarter (1976) em estudos realizados com Rhizoctonia solani Kuehn afirmam que este patógeno é o maior causador de podridão de sementes, damping-off em pré-emergência e pós-emergência do algodoeiro, exibindo vários graus de lesões e podridões, mas que a redução no crescimento de plantas, raízes e produtividade ocorrem com maior frequência em plantas danificadas pelo patógeno quando várias outras 
condições de stress estão presentes, como associado à temperaturas abaixo do normal, por exemplo

Young (1995), observou que após vários anos em monocultura, com preparo reduzido de algodão, constatou-se aumento em doenças de plântulas, e também cita a prática da rotação de culturas como medida alternativa de controle para estas moléstias.

Wang \& Davis (1997) observaram perdas de cerca de 180 mil toneladas de algodão em caroço apenas devido à ocorrência de tombamento de plântulas no ano de 1995.

Batson \& Caceres (2000), em estudos realizados durante dez anos, relataram que as doenças de plântulas são geralmente mais severas sob condições de preparo reduzido e plantio direto, e que o vigor das plantas é menor, diminuindo a produtividade.

Uma possível explicação para que ocorra maior incidência de doenças de plântulas em SPD seria pelo fato de que sob amplitudes térmicas menores, as sementes de algodoeiro exsudam maior quantidade de açúcares e aminoácidos, o que é favorável ao patógeno e estas condições também mantém a planta num estágio susceptível por um período maior, atrasando a germinação ou tornando o desenvolvimento mais lento (Cia \& Salgado, 1997), fato este comprovado por Hayman (1969), que encontrou que após 48 horas de germinação de sementes de algodoeiro, maior quantidade de exsudatos foram liberadas entre 12 e $18^{\circ} \mathrm{C}$ do que a 24,30 e $36^{\circ} \mathrm{C}$.

A modificação na temperatura e amplitude térmica do solo, ou seja, das condições microclimáticas da cultura, é um dos principais fatores de modificação da predisposição da planta àdeterminadas doenças.

Gassen \& Gassen (1996) afirmam que a manutenção da palha proporciona o aumento na atividade de microorganismos decompositores e fitopatógenos que se desenvolvem quando são cultivadas sucessivamente plantas que sejam hospedeiras das mesmas doenças, mas que a diversidade de espécies e a intensa atividade microbiana pode resultar no controle natural de alguns destes organismos patogênicos.

Os patógenos de plantas podem ser agrupados em biotróficos, que são microorganismos que dependem da planta viva para sua sobrevivência e não sobrevivem 
em restos da cultura já mortos e são disseminados por meio de esporos através do vento, água da chuva, animais, pessoas, micélio dormente, estruturas associadas à sementes e propágulos livres no solo e sua ocorrência nas lavouras é independente do sistema de preparo de solo ou de rotação de culturas. Os exemplos mais comuns são fungos como oídios (Erysiphe), míldios (Peronospora), carvões (Ustilago) e ferrugens (Puccinia, Uromyces, Phakopsora).

Há um outro grupo de organismos denominados parasitas facultativos, que apresentam um a fase de sua existência sobre o hospedeiro vivo denominada parasitária e outra saprofítica, após a morte do hospedeiro e sobrevivendo em restos de cultura saprofiticamente produzem toxinas que ajudam a matar as partes da planta e se desenvolvem sobre o material até que este esteja totalmente decomposto. Assim, a rotação com plantas que não sejam hospedeiras dos patógenos é essencial para o manejo das doenças.

A fauna do solo, por outro lado, é composta de microorganismos com hábitos alimentares diversos, podendo ser classificados como fitófagos (consumidores de plantas), em zoófagos (predadores e parasitóides de outros insetos), saprófagos (consumidores de animais e vegetais em decomposição), necrófagos (consumidores de animais e vegetais mortos) e geófagos (alimentam-se de terra). (Gassen \& Gassen, 1996). A diversidade biológica do solo é muito importante, pois determina diferentes nichos e competição entre eles, mantendo um certo nível de equilíbrio das populações.

Em sistemas sob monocultura, os patógenos necrotróficos são alimentados a cada 6-7 meses, quando a mesma espécie de hospedeiro (planta) é ressemeada na lavoura e o período para o controle está relacionado diretamente ao tempo necessário para a decomposição dos resíduos vegetais do hospedeiro. Fragmentando ou moendo palha, aumenta-se a superfície de contato desta com o solo, acelerando o processo de decomposição. (Gassen \& Gassen 1996).

Fowler \& Rockstrom (2001) encontraram que a incidência de alguns patógenos diminuiu quando comparou sistema de plantio direto com convencional, atribuindo esta redução de patógenos como resultado do aumento da matéria orgânica. Outras doenças 
que foram observadas em declínio em preparo reduzido e utilização de cobertura foram as que têm como principal via de disseminação o espirramento causado por fortes chuvas, que por causa da presença da cobertura, ficou prejudicado, pois a cobertura sobre a superfície absorve o impacto das gotas de chuva. Uma possível causa da diminuição de algumas doenças em presença de cobertura, como colocam os mesmo autores, é devido ao fato de que alguns microorganismos têm preferência à sobrevivência e desenvolvimento em restos de cultura do que na planta viva.

Além do tombamento de plântulas, o algodoeiro sofre com um grupo grande de patógenos, e as doenças são motivo de grandes perdas de produção, principalmente as doenças de manchas foliares. Bergamin Filho a Amorim (1996) afirmam que uma doença de manchas foliares comporta quatro tipos de tecidos, sendo estes o tecido latente, o tecido infeccioso, tecido removido e tecido sadio, sendo os três primeiros o tecido doente da planta. O período latente é aquele em que a doença está ocorrendo, mas, sem sintomas visíveis e não capaz de infectar nenhuma outra planta

Segundo Chiavegato (2001), há grande preocupação com o problema das doenças nas principais regiões produtoras dos cerrados, e os problemas com ramulária e Ramulose estão tomando maior vultuosidade a cada ano.

A Ramulose do algodoeiro é uma das principais doenças que vêm causando problemas nas diversas regiões de produção de algodão, é causada pelo fungo Colletotrichum gossypii South var cephalosporioides Costa, um fungo do grupo dos Ascomycetos, que é o grupo mais numeroso de fungos, possuindo cerca de 40 ordens, sendo o Colletotrichum pertencente à ordem Polystigmatales (Krugner \& Bacchi, 1995), e de acordo com Kimati et al. (1997), a doença foi constatada pela primeira vez no estado de São Paulo, em 1936, e já se encontra disseminada em praticamente todas as regiões produtoras do país, causando sérios problemas nos estados de Goiás, Mato Grosso do Sul, Mato Grosso e algumas localidades do Nordeste, podendo, em anos com condições climáticas favoráveis, chegar a perdas de produção de até $80 \%$. 
Costa \& Fraga Jr. (1939) ${ }^{1}$, baseando-se nas características morfológicas dos patógenos, consideram a hipótese de que este patógeno seria uma mutação mais agressiva do Colletotrichum gossypii South, agente causador da Antracnose do algodoeiro, mas posteriormente Follin \& Mangano $(1983)^{2}$, baseados em diferenças fisiológicas e patogênicas concluíram que esses dois fungos seriam espécies diferentes.

A doença se caracteriza inicialmente pelo aparecimento de lesões necróticas nas folhas novas, nos pontos de crescimento, seguidas pela morte do broto apical, havendo a paralização do crescimento da planta e o aparecimento de galhos extranuméricos (Abrahão \& Costa, 1954, citados por Von Pinho et al., 1997; Abrahão, 1961; Paiva et al., 2001). Von Pinho (1997), afirma que a ocorrência generalizada do patógeno surge após as quedas de temperatura que seguem as primeiras chuvas do ano agrícola, e as condições ideais para o desenvolvimento da doença são temperaturas entre 25 e $30^{\circ} \mathrm{C}$, alta umidade e precipitação pluvial. (Santos et al., 1994). Carvalho et al. (1984), constatou que as características mais afetadas do algodoeiro, em função da doença foram a produtividade, peso de capulho, comprimento e finura da fibra e peso de sementes.

A principal via de disseminação do patógeno é a semente, na qual pode ser veiculado externamente, na forma de conídios, ou internamente, na forma de micélio dormente, porém, o fungo pode sobreviver de um ano para outro em solo contaminado, podendo então, tanto ser veiculado pela semente, como pela presença e permanência no solo, em restos de cultura (Watkins 1981; Kimati, 1997).

Machado (1988) cita que o patógeno pode permanecer viável como micélio dormente por até 13 anos em condições ambientais desfavoráveis para o desenvolvimento da doença.

\footnotetext{
${ }^{1}$ COSTA, A.S.; FRAGA JUNIOR, C.G.Sobre a natureza da Ramulose. Jornal de Agronomia, v.2, p.151160, 1939.

${ }^{2}$ FOLLIN, J.C.; MANGANO, V. Estude sur Ramulose du cotonnier. Comparison du Colletotrichum responsible à C. gossypii South. Conditions d'attaques. Cotton et Fibres Tropicales, v.38, p.209-213, 1983.
} 
Dentro do campo, a disseminação ocorre tanto através de conídios produzidos em conidióforos presentes na matriz gelatinosa do acérvulo, como também por conídios presentes nas setas férteis, sendo que o primeiro tipo de conídio só é disperso por respingos de chuva e o segundo tipo são dispersos pelo movimento do ar e podem alcançar maiores distâncias. (Lenné, 1984).

Amorim (1995) afirma que a primeira fase do ciclo das relações patógenohospedeiro, que serve para diferenciar o ciclo primário do ciclo secundário é a sobrevivência do inóculo, e esta fase caracteriza-se por garantir a sobrevivência do agente patogênico em situações adversas como condições climáticas desfavoráveis ou ausência do hospedeiro. A sobrevivência do patógeno ocorre com patógenos de culturas anuais, onde as plantas morrem ao final do ciclo, pois são obrigados a suportar prolongados períodos de tempo na ausência de tecido suscetível. No caso do grupo dos Ascomycetos, no qual se insere o gênero Coletotrichum, as estruturas de resistência são os ascósporos, que funcionam como estruturas de sobrevivência, e sua liberação ocorre durante todo o ciclo da doença, de forma homogênea.

Menten (1986) afirma que a transmissão de Colletotrichum gossypii var cephalosporioides Costa, ou de qualquer outro patógeno transmitido por sementes deve ser avaliada tanto pela transferência e estabelecimento do patógeno da semente para a planta, como também da planta-mãe para a semente. Machado (1994) relata que tanto a transmissão da semente para a planta, como da planta para as sementes produzidas são influenciadas pelo ambiente e por características do patógeno e do hospedeiro e Tanaka (1990) encontrou em seus estudos que nem sempre a resistência da planta adulta está relacionada com a resistência no estádio de plântula, com a porcentagem do patógeno nas sementes, ou a porcentagem de transmissão semente-plântula.

Cia \& Fuzatto (1986) recomendam não utilizar sementes para plantio, provenientes de campos de produção onde ocorra mais de 5\% de plantas com Ramulose, no entanto, onde o patógeno já se encontra disseminado e quando se utiliza cultivares resistentes, pode haver um padrão menos rigoroso para a não aprovação de um campo de produção de sementes. 
Menten (1997) afirma que como diretrizes gerais, deve-se considerar que os padrões estabelecidos não venham inviabilizar o sistema de produção de sementes, fixando valores muito rígidos que levem à rejeição da maior parte dos lotes, mas concorda que o ideal seria a tolerância zero, ou seja, a ausência de patógenos. Para os padrões de sanidade de sementes ou níveis de tolerância em programa de certificação, o mesmo autor propõe que para sementes básicas, a tolerância de $C$. gossypii var cephalosporioides Costa seja zero, para sementes certificadas seja $1 \%$ e para sementes fiscalizadas seja $2 \%$ de sementes infectadas com o patógeno no lote.

Pizzinatto et al. (1993) estudaram a relação entre a severidade de Ramulose em genótipos de algodoeiro com diferentes níveis de resistência à Ramulose e a presença de patógenos nas sementes produzidas a concluíram que nem sempre houve uma relação entre a infecção de plantas com diferentes níveis de resistência à Ramulose e a presença de Colletotrichum gossypii var cephalosporioides nas sementes produzidas.

Um estudo realizado por Santos et al. (1993), constatou que o índice de doença na planta não se correlacionou com a porcentagem de infecção em sementes, porcentagem de emergência e transmissão semente plântula, mas que quanto maior a percentagem de infecção nas sementes, maior a transmissão semente-plântula. $\mathrm{O}$ autor observou que as fases mais susceptíveis da planta ao patógeno correspondem aos períodos de 25,35 , e 45 dias após a emergência, em ordem decrescente de prédisposição e a inoculação durante o período de maçãs em desenvolvimento possibilitou maior recuperação do fungo nas sementes, menor emergência e maior transmissão semente-plântula.

Segundo Cia \& Fuzatto (1999), o principal método de controle de doenças do algodoeiro é a utilização de cultivares resistentes, associando com outras medidas integradas. Para as novas regiões produtoras têm-se dado maior atenção ao melhoramento de cultivares principalmente para resistência à Colletotrichum gossypii var cephalosporioides Costa, devido à importância desta doença fúngica. (Cia et al. 2001). 


\subsection{Relação Clima X Doenças}

O desenvolvimento de uma doença em determinado local é resultante da interação entre uma planta suscetível, um agente patogênico e das condições ambientais favoráveis. Assim, o ambiente é de extrema relevância nesta interação, podendo impedir a ocorrência da doença mesmo em presença de hospedeiro suscetível e fonte de inóculo se as suas condições meteorológicas não forem favoráveis, onde doenças causadoras de grandes prejuízos podem se tornar menos perigosas. (Bedendo, 1995; Bergamin Filho \& Amorim, 1996).

De acordo com Chiavegato (1995), o ambiente é definido como o conjunto de condições e fatores adversos ou favoráveis, presentes no local de produção e constitui-se em variável importantíssima que, em qualquer fase do desenvolvimento pode atuar modificando a produção e a qualidade do produto final.

Bedendo (1995) afirma que o desenvolvimento e a produção de uma espécie vegetal dependem do seu genótipo e das condições ambientais que podem atuar sobre suas características. Os elementos meteorológicos (umidade, temperatura, luz e vento) podem ser responsáveis pela predisposição das plantas ao ataque de patógenos.

Zalher et al. $(1991)^{3}$, afirmam que entre os elementos meteorológicos que influenciam o desenvolvimento do hospedeiro e patógeno, podem ser citados como principais a umidade do ar, temperatura, precipitação pluvial e o vento, e Sutton et al. (1984) salientam que a observação contínua dessas variáveis, do desenvolvimento da cultura e do patógeno são primordiais para entender e quantificar estas inter-relações.

Para a cultura do algodoeiro, Chiavegato (1995), estudando o efeito do ambiente e de cultivares nos componentes da produção e características tecnológicas das fibras e do fio concluiu que a influência do ambiente na produção do algodão em caroço

3 ZALHER, D.M.; MOTA, F.S.; AGENDES, M.O.O. Previsão agrometeorológica no controle de doenças e pragas. Brasília: Ministério da Agricultura e Reforma Agrária, 1991, 54 p. 
foi dez vezes maior à de cultivar, provando que as condições edafoclimáticas da região pode atuar favorecendo ou inibindo tanto os componentes de produção da planta quanto o desenvolvimento de patógenos e pragas.

Pedro Jr. (1989) ${ }^{4}$, citado por Monteiro (2003) salienta que as doenças fúngicas que se desenvolvem nas folhas $\mathrm{e}$ frutos são influenciadas principalmente pelo macroclima da região, mas que o sombreamento, utilização de quebra ventos, cobertura morta e outras técnicas podem modificar o microclima da comunidade vegetal, alterando a temperatura e umidade do ar, influenciando no processo infeccioso e desenvolvimento da doença.

\subsection{Influência da palhada no microclima e ocorrência de doenças}

Em se tratando de desenvolvimento de doença, as condições ambientais no interior do dossel (microclima) são determinadas pelo macroclima do local, arquitetura da planta e cobertura na superfície do solo. Para Rotem \& Palti (1969), o microclima de uma cultura é resultante da densidade de plantio, topografia, tipo de solo, drenagem e fatores culturais. O microclima no interior do dossel também pode ser modificado quando a cultura á exposta à uma condição não usual, incorrendo a mudanças no comportamento dos patossistemas. (Rotem, 1988). Agrios (1997) afirma que doenças de plantas podem ocorrer sob ampla faixa de condições ambientais e que as técnicas culturais podem transformar ambientes adversos em ambientes favoráveis ao desenvolvimento da doença.

\footnotetext{
4 PEDRO JUNIOR, M.J. Aspectos microclimáticos e epidemiologia. In: Curso prático internacional de agrometeorologia para a otimização da irrigação, 3. Campinas. Instituto Agronômico de Campinas, 1989, $13 \mathrm{p}$.
} 
O tipo de cobertura do solo influencia no balanço de energia local,intensificando o efeito microclimático, tanto no aquecimento diurno como no resfriamento noturno (Pereira et al., 2002). O microclima formado no interior do dossel da cultura, aliado ao tipo de cobertura, vão satisfazer ou não as condições necessárias para a sobrevivência do patógeno e ocorrência de infecção. Fowler \& Rockstrom (2001) afirmam que a presença de resíduos na superfície do solo tem sido vista como razão para aumentarem os problemas de pragas e doenças em preparos conservacionistas.

Resíduos de plantas na superfície do solo afetam sua temperatura e umidade, (Adams, 1960; Fowler \& Rockstrom, 2001) e também a germinação das plantas (Benoit \& Lindstrom, 1987), tanto da cultura como de plantas daninhas. Gupta et al. (1983), afirmam que o maior efeito dos resíduos na superfície é a depressão da temperatura do solo na zona das sementes e que resíduos na superfície também influenciam no crescimento das raízes, disponibilidade de Nitrogênio, infestação de daninhas e insetos e degradação de herbicidas e inseticidas. Gassen \& Gassen (1996) afirmam que há grande diferença quando se mede a temperatura do solo nú e a do solo coberto com palhada, também em relação à temperatura do ar, sendo que por ordem decrescente estão solo nu, solo com palhada e temperatura do ar, e que estas diferenças ocorrem com maior intensidade nos horários mais quentes do dia, quando a umidade relativa é mais baixa, o que foi comprovado por Monteiro (2002) que também encontrou diferenças na temperatura do ar e da superfície vegetada, mostrando que quanto mais massa verde houver na área, maior a umidade relativa, portanto, maior a duração do período de molhamento foliar.

A alteração da temperatura modifica o conteúdo de água do solo, fluxo de gases, estrutura, decomposição de resíduos, ciclagem e quantidade de nutrientes, espectro e competição de plantas daninhas e a dinâmica de doenças de plantas. (Fowler \& Rockstrom, 2001). Em regiões tropicais e subtropicais, a cobertura é essencial para minimizar os efeitos deletérios de chuvas intensas, redução de altas temperaturas do solo e diminuir evaporação, e que em regiões com problema de escorrimento superficial, a utilização de palha é uma alternativa para sanar o problema, inclusive de armazenamento 
de água. (Adams 1966) Entretanto, em regiões muito úmidas e temperaturas elevadas, manter a cobertura as superfície dos solos é tarefa difícil, pois a taxa de decomposição nestas regiões mais quentes é muito alta. Army (1961) afirma que a presença de resíduos na superfície do solo também promove a diminuição do movimento do ar imediatamente acima do solo.

O aumento do uso de preparo conservacionista dos solos e novos conceitos de manejo integrado de pragas necessita de conhecimentos de temperatura do solo e outros parâmetros físicos para maximizar a exploração das alternativas de manejo, reduzindo a erosão do solo e mantendo energia pela redução do preparo. A temperatura do solo nos primeiros $30 \mathrm{~cm}$ do perfil são de grande utilidade para decidir muitas das práticas de manejo. (Gupta et al., 1984). Os mesmos autores concordam que mantendo o solo coberto com resíduos, prática comum nos sistemas de preparo reduzido, há modificações no regime térmico do solo, confirmado em experimento realizado por eles, em que foram medidas as temperaturas em solo sem preparo e sem resíduos, solo sem preparo e com resíduo e solo com preparo convencional com utilização de resíduos, e concluíram que as mudanças de temperaturas estão mais relacionadas à cobertura do solo do que ao sistema de preparo ou nível de distúrbio do solo, ou seja, nos tratamentos em que havia presença de cobertura, a temperatura foi inferior, mesmo nos que utilizaram o preparo convencional, ou revolvimento do solo.

Benoit \& Lindstrom (1987) afirmam que a modificação do regime térmico do solo quando se utilizam restos de cultura ocorre por causa da reflectância dos diferentes materiais expostos na superfície. A reflectância varia com o tipo de planta, cor, e conteúdo de água no solo. Atentam ainda para o fato de que superfícies vegetadas refletem mais que superfícies de solo nuas, e solos úmidos refletem menos que solos secos. O aumento da reflectância resulta em menor radiação líquida que atinge a superfícies, resultando em menores temperaturas do solo.

Tem sido estudada e detectada a influência da temperatura em todas as fases do desenvolvimento dos microorganismos no processo de infecção, desde a germinação dos esporos até a produção de novas unidades de reprodução (Rotem, 1978), mas esta 
influência é menor do que a encontrada pelas condições de umidade, que em regiões tropicais e subtropicais exercem papel limitante no desenvolvimento de epidemias (Agrios, 1997), porém, quando as condições de temperatura são muito diferentes do ótimo para que a doença se desenvolva, a taxa de desenvolvimento é reduzida, ocorrendo um decréscimo no número de infecções e diminuição do inóculo (Rotem, 1978), modificação da duração do período de germinação de esporos, penetração, colonização e reprodução, afetando tanto a velocidade de reprodução quanto a quantidade de propágulos. (Bedendo, 1995).

Em relação à cultura do algodoeiro e sua interação com o Coletotrichum gossypii var cephalosporioides Costa, houve aumento da incidência aos 81 dias, com umidade relativa de $90,2 \%$ e $18,3^{\circ} \mathrm{C}$ de temperatura. (Santos, 1993).

A presença de cobertura morta na superfície do solo, além de modificar a temperatura no interior do dossel, também modifica as condições de umidade, ou Duração do Período de Molhamento Foliar (DPM). Rotem (1978) relata a importância da duração do período de molhamento foliar para o desenvolvimento de doenças, que é determinado pela cobertura da folha com uma película de água, devido à ocorrência de orvalho, chuva ou irrigação. Os diferentes patógenos necessitam de diferentes condições de molhamento foliar para que possam se desenvolver e colonizar o hospedeiro, associado à temperatura. (Yarword (1956); Horsford et al. (1987). Allen et al. (1983) afirmam que para a maioria dos patógenos são necessárias pelo menos duas a seis horas de molhamento para ocorrer alguma infecção. 


\section{MATERIAL E MÉTODOS}

\subsection{Local e período de condução}

O experimento foi conduzido em área da Fazenda Areão, pertencente à Escola Superior de Agricultura “ Luiz de Queiroz” USP/ESALQ, localizada no município de Piracicaba-SP, no ano agrícola 2002/03.

A área experimental está situada a $546 \mathrm{~m}$ de altitude, latitude de $22^{\circ}$ e $42^{\prime} \mathrm{S}$ e longitude de $47^{\circ}$ e $37^{\prime}$ W. O clima da região é do tipo Cwa (clima mesotérmico, úmido, subtropical com inverno seco), segundo a classificação de Koeppen (Vianello \& Alves, 1991). A temperatura média do mês mais quente está acima de $24^{\circ} \mathrm{C}$ e a do mês mais frio abaixo de $17^{\circ} \mathrm{C}$, apresentando uma precipitação pluvial média anual de $1200 \mathrm{~mm}$.

\subsection{Caracterísiticas do solo}

O solo do local da experimentação foi amostrado, e as amostras retiradas na profundidade de 0-20 cm, e encaminhadas ao Laboratório de Análises Químicas do Solo, do Departamento de Solos e Nutrição de Plantas da USP/ESALQ, para a caracterização química. É classificado como Terra Roxa Estruturada Eutrófica e os teores de macro e micronutrientes, são apresentados nas Tabelas 1 e 2. 
Tabela 1. Resultados da análise química do solo para macronutrientes da área experimental, na profundidade de 0-20 cm. Piracicaba, SP. 2001

\begin{tabular}{|c|c|c|c|c|c|c|c|c|c|c|}
\hline $\mathrm{PH}$ & M.O. & $\mathrm{P}$ & $\mathrm{S}-\mathrm{SO}_{4}$ & $\mathrm{~K}$ & $\mathrm{Ca}$ & $\mathrm{Mg}$ & $\mathrm{H}+\mathrm{A}$ & SB & $\mathrm{T}$ & V \\
\hline $\mathrm{CaCl}_{2}$ & g.dm ${ }^{-3}$ & \multicolumn{2}{|c|}{ mg.dm ${ }^{-3}$} & \multicolumn{6}{|c|}{ Mmolc. $\mathrm{dm}^{-3}$} & $\%$ \\
\hline 4,9 & 21 & 23 & 50 & 5,2 & 29 & 21 & 34 & 55,2 & 89,2 & 62 \\
\hline
\end{tabular}

Tabela 2. Resultados da análise química do solo para micronutrientes da área experimental, na profundidade de 0-20 cm. Piracicaba, SP. 2001

\begin{tabular}{ccccc}
\hline B & Cu & $\begin{array}{c}\text { Fé } \\
{\mathrm{Mg} . \mathrm{dm}^{-3}}^{-3}\end{array}$ & $\mathrm{Mn}$ & $\mathrm{Zn}$ \\
\hline 0,24 & 4,3 & 21 & 20,6 & 1,7 \\
\hline
\end{tabular}

\subsection{Cultivares utilizadas}

3.3.1 IAC 23 - Tem origem na linhagem IAC RR-97/86, obtida por melhoramento genético para resistência à Ramulose através de seleções sucessivas na cultivar IAC 20. Apresenta elevado desempenho agronômico, com potencial produtivo de 187 @/ha e porcentagem de fibra de 40\%. Ciclo da semeadura à colheita de 155 a 165 dias, ciclo até o florescimento de 45 a 50 dias, resistente à Ramulose e mancha-angular, moderadamente resistente à murcha de Fusarium, murcha de Verticillium, murchamento avermelhado, nematóides, virose das nervuras e suscetível à mancha de Stemphyllium. (Cia e Fuzatto, 2002).

3.3.2 Makina - É uma cultivar semi-precoce, com ciclo de aproximadamente 160 dias, com florescimento em aproximadamente 48 dias após a emergência, alta 
performance em produtividade, hábito de crescimento determinado, altura média de 1,10m quando manejada com regulador de crescimento, não pilosa e fibra de alta qualidade. Em relação à doenças, é uma cultivar suscetível à vários patógenos fúngicos, com destaque à Ramulose, doença fúngica de interesse nesta pesquisa . (Catálogo Syngenta seeds, 2000)

\section{4 Monitoramento das variáveis meteorológicas}

Foram coletados dados meteorológicos de precipitação pluvial, temperaturas máxima, média e mínima, umidade relativa do ar, radiação solar, insolação e velocidade média do vento, registrados no período de setembro de 2002 a maio de 2003 pelo Posto Agrometeorológico do Departamento de Ciências Exatas da USP/ESALQ. Na Tabela 3 encontram-se os dados médios normais dos elementos meteorológicos no local, do período de 1917 à 2000 .

Tabela 3. Dados médios mensais dos elementos meteorológicos do período de 1917 à 2000. Piracicaba, SP

\begin{tabular}{|c|c|c|c|c|c|c|c|c|}
\hline Mês & $\begin{array}{c}\text { Rad. Global } \\
(\mathrm{MJ} / \mathrm{m} 2 / \mathrm{d})\end{array}$ & $\begin{array}{l}\text { Insolação } \\
\text { (horas/dia) }\end{array}$ & $\begin{array}{c}\text { Precipitação } \\
(\mathrm{mm})\end{array}$ & $\begin{array}{c}\text { Umidade Rel. } \\
(\%)\end{array}$ & $\begin{array}{c}\text { Vento médio } \\
(\mathrm{km} / \text { hora })\end{array}$ & T máxima & $\begin{array}{c}\text { T mínima } \\
\text { oC }\end{array}$ & $\mathrm{T}$ média \\
\hline set & 15,8 & 6,8 & 63,9 & 65 & 9,3 & 28,1 & 13,4 & 20,7 \\
\hline out & 18,2 & 6,9 & 110,3 & 69,7 & 9,8 & 28,9 & 15,6 & 22,3 \\
\hline nov & 19,8 & 7,4 & 130,4 & 69,8 & 9,7 & 29,6 & 16,7 & 23,1 \\
\hline dez & 18,8 & 6,6 & 201 & 74,5 & 8,9 & 29,6 & 18,2 & 23,9 \\
\hline jan & 18,8 & 6,4 & 224,5 & 76,3 & 7,8 & 30 & 19 & 24,4 \\
\hline fev & 18,4 & 6,5 & 184,1 & 76,4 & 7,4 & 30,2 & 19 & 24,6 \\
\hline mar & 16,7 & 6,8 & 143,2 & 76,1 & 7,2 & 30 & 18,2 & 24,1 \\
\hline abr & 15,6 & 7,5 & 63,6 & 74,1 & 7,1 & 28,4 & 15,4 & 21,8 \\
\hline mai & 12,6 & 7,3 & 52,1 & 75,2 & 6,4 & 26,1 & 12,1 & 19,1 \\
\hline
\end{tabular}

Fonte: Departamento de Ciênciasexatas USP/ESALQ.

O objetivo inicial do estudo foi medir as condições de temperatura e umidade sob o dossel das plantas nos tratamentos, a fim de verificar as possíveis diferenças microclimáticas entre os sistemas com e sem palha. Para tanto foram instalados 
psicrômetros no centro das subparcelas, conectados à uma estação meteorológica modelo CR-10 no centro da área experimental. Não foi possível dar continuidade à estas avaliações pela falta de energia para manter os equipamentos ligados durante todo o ensaio, de modo que os dados coletados foram perdidos.

\subsection{Delineamento experimental}

O delineamento experimental utilizado foi o de parcelas subdivididas em esquema fatorial $2 \mathrm{X} 2$ (split-plot), constando de 4 repetições. As parcelas são as 4 faixas, alternados entre plantio na palha (blocos de 1 e 3), e plantio convencional (blocos de 2 e 4), e dentro de cada parcela, estão distribuídas ao acaso as subparcelas com cultivar resistente (IAC 23) e suscetível (Makina). Cada subparcela contou com 6 linhas de 5 metros de comprimento, sendo as 4 linhas centrais consideradas úteis e as duas laterais bordadura. Espaçamento entre-linhas de 0,9 metros e densidade de 08 plantas/metro linear.

Os dados obtidos através das avaliações foram submetidos à análise de variância e as médias comparadas pelo teste $\mathrm{F}$, a 5 \% de probabilidade.

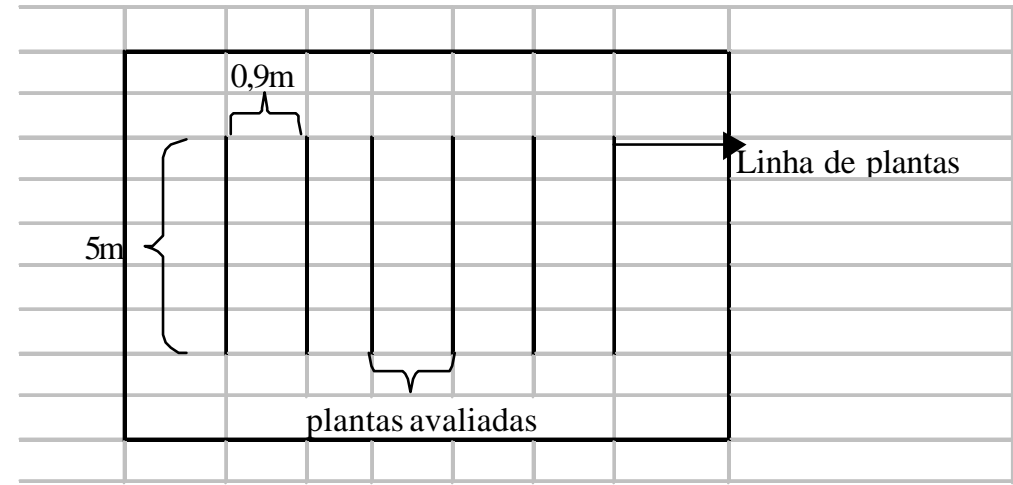

Figura 1- Esquema da subparcela experimental. Ano agrícola 2002/03. Piracicaba, SP 
Na Tabela 4 estão descriminados os tratamentos:

Tabela 4. Tratamentos utilizados: Ano agrícola 2002/03. Piracicaba, SP

\begin{tabular}{lccccc}
\hline \multicolumn{1}{c}{ Tratamentos } & Cultivares & C/ Palha & S/ Palha & C/ Inoculação & S/ Inoculação \\
\hline cult. resistente,inoculada, com palha & IAC 23 & $\mathrm{X}$ & & $\mathrm{X}$ & \\
testemunha não inoculada & IAC 23 & $\mathrm{X}$ & & & $\mathrm{X}$ \\
cult. suscetível, inoculada, com palha & Makina $^{2}$ & $\mathrm{X}$ & & $\mathrm{X}$ & \\
testemunha não inoculada & Makina & $\mathrm{X}$ & & & $\mathrm{X}$ \\
cult. resistente, inoculada, sem palha. & IAC 23 & & $\mathrm{X}$ & $\mathrm{X}$ & \\
testemunha não inoculada & IAC 23 & & $\mathrm{X}$ & & $\mathrm{X}$ \\
cult. suscetível, inoculada, sem palha & Makina & & $\mathrm{X}$ & $\mathrm{X}$ & $\mathrm{X}$ \\
testemunha não inoculada & Makina & $\mathrm{X}$ & & $\mathrm{X}$ \\
\hline
\end{tabular}

(1) IAC 23: Cultivar resistente à Ramulose

(2) Makina: Cultivar suscetível à Ramulose

\section{6 Implantação e condução do experimento}

A área experimental foi cultivada com o algodoeiro na safra anterior e mantida em pousio após a colheita. Foi realizado um preparo de base no solo (2 de setembro de 2002), com arado de disco e uma gradagem leve. Após o preparo de base, foram demarcados os 4 bocos (palhada e convencional).

3.6.1 Período anterior à semeadura do algodoeiro

a) Blocos destinados à produção de palhada (1 e 3$)$

Para a produção de palhada nos blocos destinados à este fim, foi semeado o Milheto (Pennisetum glaucum L.), cultivar BN-2, muito utilizado em sistemas de plantio direto. O Milheto é uma espécie da família Poaceae, segundo classificação de Cronquist (1981), citado por Capellari Jr. et al (2002) e a cultivar utilizada apresenta produção de massa verde de 40-50 t/ha e 8-10 t/ha de massa seca, podendo chegar à altura de 1,0 a $2,5 \mathrm{~m}$. Tem hábito de crescimento em touceira/ereto, ciclo até o florescimento de 60-90 
dias, como padrões mínimos de qualidade: $60 \%$ de germinação e 95\% de pureza (Piraí Sementes ${ }^{5}$ ).

A partir das sementes da cultivar utilizada no ensaio, foram feitas amostragens homogêneas e estas submetidas ao teste de germinação. $O$ teste de germinação foi realizado no Laboratório de Análise de Sementes do Departamento de Produção Vegetal, setor de sementes da USP/ESALQ, e efetuado segundo metodologia descrita nas Regras para Análise de Sementes. (Ministério da Agricultura, 1992)

A semeadura do milheto foi realizada no dia 06 de Setembro de 2002, manualmente (à lanço), na quantidade de $30 \mathrm{~kg} / \mathrm{ha}$ nos blocos que seriam destinados à formação de palhada, e foi conduzida até o florescimento (60 dias após a emergência).

Considerando que a precipitação pluvial nesta época do ano é muito baixa, o que poderia prejudicar o estande da cobertura, e o tempo para o desenvolvimento vegetativo disponível é mais curto, a quantidade semeada foi acima da recomendada para garantia da emergência das plântulas e posterior formação da cobertura.

Foi realizada uma adubação de cobertura do milheto no dia 30 de setembro de 2002 (24 DAE), com 100 kg Sulfato de Amônio/ha, à lanço. O blocos foram irrigados diariamente por meio de irrigação por aspersão para garantir o desenvolvimento satisfatório das plantas.

Com 73 dias após a semeadura (19 de novembro de 2002), ou 60 DAE, foram retiradas 3 amostras da cobertura verde para determinação de massa seca produzida na área. Para a amostragem foi utilizado um quadro de $1 / 2 \mathrm{~m}^{2}$, e as plantas foram cortadas no nível do solo e acondicionadas em sacos de papel, secas em estufa à $70^{\circ} \mathrm{C}$ até peso constante.

\footnotetext{
${ }^{5}$ Informações contidas na embalagem do produto
} 


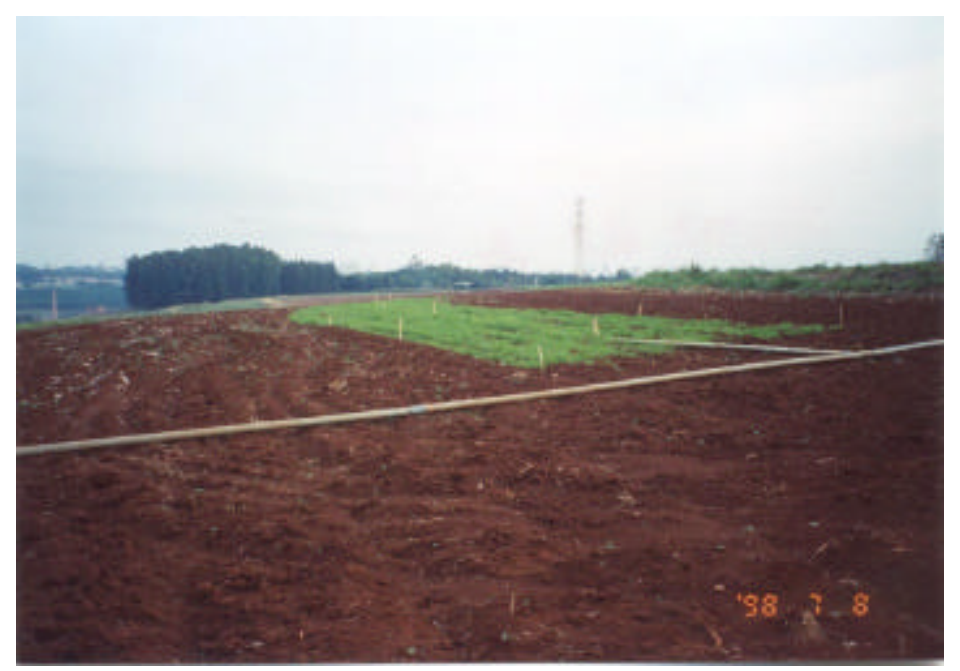

Figura 2- Detalhe de faixa com milheto em desenvolvimento e irrigação por aspersão. Ano agrícola 2002/03. Piracicaba, SP

Os dados obtidos a partir dos pesos das plantas secas estão discriminados na tabela a seguir:

Tabela 5. Peso em gramas das amostras de plantas de milheto coletadas e secas em estufa à $70^{\circ} \mathrm{C}$, até peso constante. Ano agrícola 2002/03. Piracicaba. SP

\begin{tabular}{ccc}
\hline Amostra & Bloco (parcela) & Peso $(\mathrm{g})$ \\
\hline 1 & 1 & 312 \\
2 & 1 & 241 \\
3 & 1 & 280 \\
4 & 3 & 270 \\
5 & 3 & 290 \\
6 & 3 & 300 \\
\hline
\end{tabular}

A partir das amostras, obteve-se a média simples de 283 gramas de massa seca por $1 / \mathrm{m}^{2}$, conseqüentemente $5,7 \mathrm{t} / \mathrm{ha}$ de matéria seca. 
No mesmo dia (19 de novembro de 2002), foi realizada a dessecação das plantas de milheto, com o herbicida de ação total Gliphosate, na dose de 4 1/ha, aplicado com pulverizador de barras.

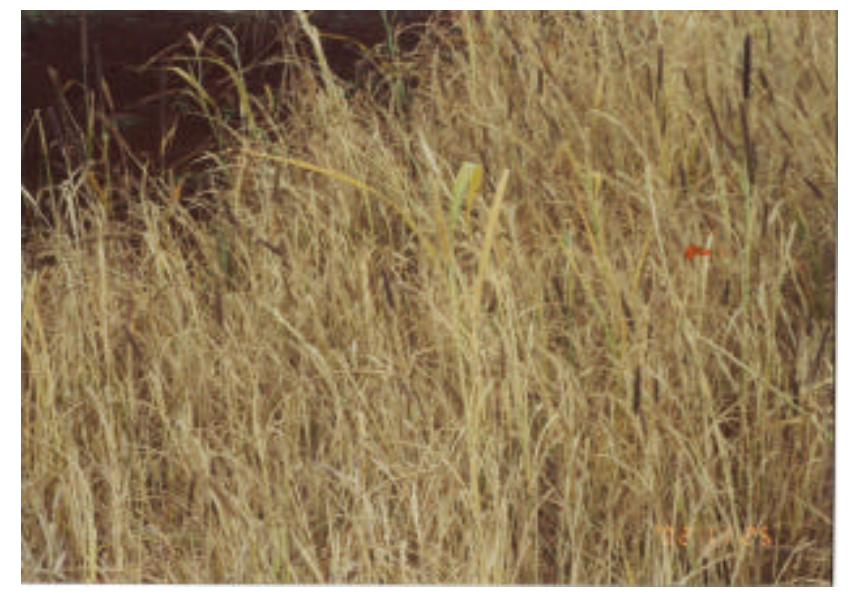

Figura 3- Plantas de milheto 7 dias após dessecação. Ano agrícola 2002/03. Piracicaba, SP

b) Blocos de preparo convencional (blocos 2 e 4 )

Os dois blocos destinados à semeadura convencional do algodoeiro permaneceram em pousio após o preparo de base, já mencionado. Por ocasião da semeadura do algodoeiro, em 28 de novembro de 2002, foi realizada apenas uma gradagem leve para eliminação das plantas daninhas da área. Não foi utilizado herbicida em pré-plantio.

Antes da semeadura do algodoeiro foi realizado o teste de sanidade das sementes das cultivares no Laboratório de Patologia de Sementes do Departamento de Entomobgia, Fitopatologia e Zoologia Agrícola, da USP/ESALQ, através do método do Papel de Filtro, descrito por Neergard (1997), para certificação de que o lote não estava previamente contaminado com o fungo Colletotrichum gossypii spp. 
3.6.2 Semeadura do algodoeiro e condução do experimento

a) Semeadura

A cultura foi semeada no dia 28 de novembro de 2002, com semeadora mecânica S.H.P. 236 - SEMEATO - Semeadora hidráulica de parcelas, específica para utilização em plantio direto de parcelas experimentais. O espaçamento utilizado foi de 0,9 m entre linhas, sendo possível semear 2 linhas de cada vez dentro dos blocos experimentais (parcelas)

A mesma semeadora foi utilizada tanto para as faixas com palhada, como para as faixas de plantio convencional, para garantir a uniformidade de profundidade de semeadura, mantendo a posição das sementes e adubo nos sulcos em toda a área experimental.

A quantidade de sementes em cada parcela foi de $100 \mathrm{~g}$ de semente/parcela, calculado conforme a porcentagem de plântulas normais do teste de germinação, acrescentando-se $20 \%$ para garantia do estande definitivo.

b) Adubação

A adubação de base foi feita simultaneamente à semeadura, com semeadora, utilizando-se $375 \mathrm{~kg}$ da fórmula 420-20/ha e a adubação de cobertura foi parcelada em duas vezes, sendo a primeira no dia 08 de janeiro de 2003 , com $50 \mathrm{~kg} / \mathrm{ha}$ de $\mathrm{N}$, e a segunda no dia 13 de fevereiro de 2003, com 40 kg/ha de Nitrogênio, num total de 90 $\mathrm{kg} / \mathrm{ha}$ de nitrogênio aplicados em cobertura. 
c) Emergência e desbaste

A emergência ocorreu no dia 05 de dezembro, e aos 33 dias após a emergência foi realizado o ajuste do estande, deixando-se 08 plantas/metro linear nas linhas das parcelas. Na Figura 4 (A e B) estão os detalhes de emergência nos dois sistemas de semeadura.
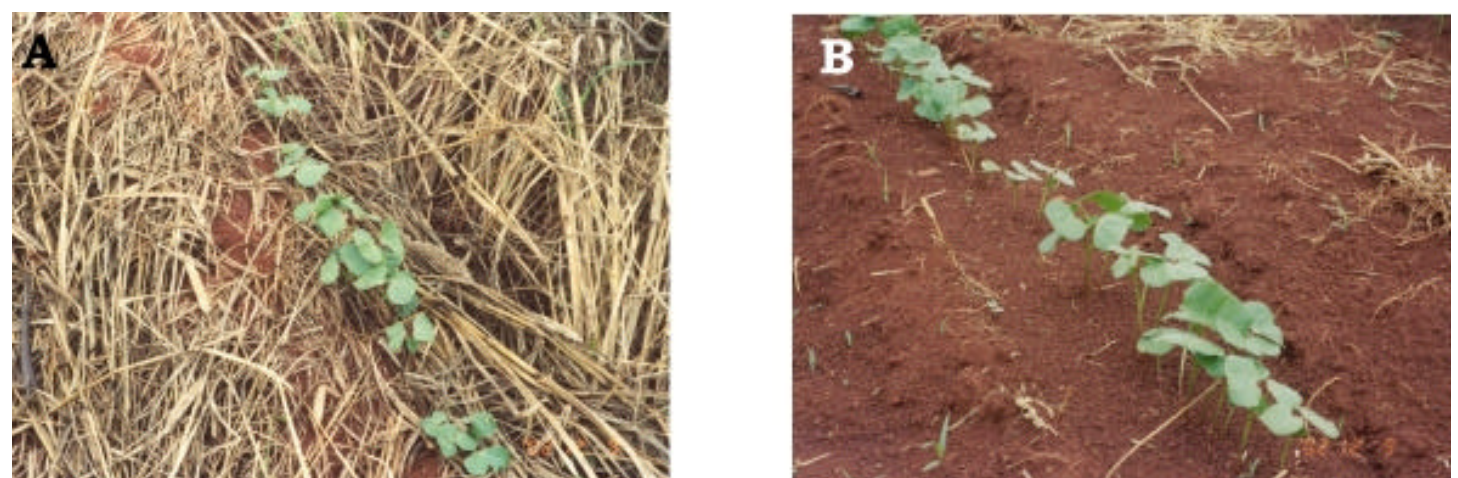

Figura 4 - Detalhe de emergência na semeadura sobre a palha (A), e da emergência na semeadura convencional (B). Ano agrícola 2002/03. Piracicaba, SP

d) Controle fitossanitário e de plantas daninhas

Foi realizado o controle preventivo e curativo das principais pragas de ocorrência na cultura do algodoeiro, como o bicudo do algodoeiro (Anthonomus grandis Boh), pulgões (Aphis gossypii Glover), tripes (Frankliniella sp.), ácaro branco (Polyphagotarsonemus latus Banks), curuquerê do algodoeiro (Alabama argilaceae), etc. através aplicações semanais de inseticidas, alternando os princípios Endosulfan, Deltametrina e Monocrotophos

No controle de plantas daninhas da área, foi realizada uma aplicação de herbicida graminicida pós emergente no dia 3 de janeiro de 2003, aos 29 dias após a emergência e capinas manuais nas entrelinhas sempre que necessário, principalmente na área com palha, onde observou-se uma rebrota considerável das plantas de milheto. 
e) Monitoramento do crescimento das plantas

Foi realizada uma única aplicação de regulador de crescimento, PIX (Cloreto de mepiquat) em todas as parcelas experimentais aos 58 dias após a emergência, na dose de 0,4 1/ha, principalmente por causa das testemunhas não inoculadas, as quais não tinham seu crescimento limitado pela doença. A aplicação foi realizada com pulverizador costal de $\mathrm{CO}_{2}$, com pressão constante de 42 1.pol ${ }^{-2}$ e bico $\mathrm{X}_{2}$.

f) Colheita

Foram coletadas amostras de 20 capulhos do terço médio das plantas das linhas úteis de forma aleatória em cada subparcela experimental, antes da colheita, para que determinação dos caracteres agronômicos de laboratório (massa média de um capulho, massa de 100 sementes, e porcentagem de fibra), e das características tecnológicas das fibras através do equipamento HVI (High Volume Instrument) da Zellweger Uster/Spinlab série 900 do Centro de Plantas Fibrosas do Instituto Agronômico de Campinas.

A colheita foi realizada manualmente, aos 165 DAE, com aproximadamente $100 \%$ de maçãs abertas, e o material colhido foi pesado para avaliação de produção e produtividade.

\subsubsection{Inoculação do patógeno nos tratamentos}

A inoculação das plantas com o Coletotrichum gossypii var cephalosporioides Costa, agente causador da Ramulose do algodoeiro, foi realizada no dia 08 de janeiro de 2003 (34 DAE), com inóculo fornecido pelo Centro de Pesquisa e Fitossanidade da Agência Paulista de Tecnologias dos Agronegócios (Instituto Agronômico de Campinas, centro experimental central), numa mistura de cinco isolados do patógeno, onde as culturas foram desenvolvidas em meio sólido e após o período de incubação, foi preparada a suspensão de esporos. 
Para o preparo do inóculo, foram adicionados 15 a $20 \mathrm{ml}$ de água destilada em cada placa de Petri contendo a cultura do fungo, sendo removida a parte superficial da colônia. O material resultante foi misturado, completando-se o volume a 2 litros de água destilada, e em seguida, filtrado em duas camadas de gaze, obtendo-se a suspensão de conídios. Esta suspensão com concentração aproximada de $1 \times 10^{6}$ conídios $/ \mathrm{mL}$ foi aplicada com pulverizador costal de $\mathrm{CO}_{2}$ com pressão constante de 421. pol $^{-2}$ e bico $\mathrm{X}_{2}$.

Não foi realizada mais de uma inoculação porque foram observados os primeiros sintomas alguns dias depois, e esse desenvolvimento inicial satisfatório da doença. ocorreu principalmente devido às condições meteorológicas favoráveis ao processo de infecção, como pode-se observar nas Tabelas 6, com dados das condições meteorológicas de dois meses anteriores à inoculação e do mês da inoculação e na Tabela 7 com dados meteorológicos no dia da inoculação.

Os tratamentos foram inoculados no final da tarde, evitando-se a incidência de radiação solar e sob temperatura mais amena, a fim de favorecer a infecção. A aplicação foi concentrada na região apical das plantas, por ser a região da planta mais sensível à Ramulose (Santos et al, 1984)

Tabela 6. Condições meteorológicas dos dois meses anteriores à inoculação. Ano agrícola 2002/03. Piracicaba, SP

\begin{tabular}{cccccccc}
\hline Mês & T máx & T mín & T média Precipitação & $\begin{array}{c}\text { Umid. Relativa } \\
\text { \% }\end{array}$ & $\begin{array}{c}\text { Radiação } \\
\text { cal/cm2/dia }\end{array}$ & $\begin{array}{c}\text { Vento médio } \\
\text { km/hora }\end{array}$ \\
\hline Novembro & 30,6 & 18,8 & 24,7 & 176,4 & 81,1 & 432,2 & 9,7 \\
Dezembro & 31,2 & 19,7 & 25,4 & 164,7 & 85,7 & 460,74 & 7,9 \\
Janeiro & 29,6 & 20,2 & 24,9 & 302,4 & 83,12 & 362 & 6,6 \\
\hline
\end{tabular}

Tabela 7. Condições meteorológicas no dia da inoculação. Ano agrícola 2002/03. Piracicaba, SP

\begin{tabular}{ccccccc}
\hline T máx & $\begin{array}{c}\text { T mín T média } \\
\text { OC }\end{array}$ & $\begin{array}{c}\text { Precipitação } \\
\mathrm{mm}\end{array}$ & $\begin{array}{c}\text { Umid. Relativa } \\
\%\end{array}$ & $\begin{array}{c}\text { Radiação } \\
\text { cal/cm2/dia }\end{array}$ & $\begin{array}{c}\text { Vento médio } \\
\mathrm{km} / \mathrm{hora}\end{array}$ \\
\hline 32.3 & 17.2 & 24.8 & 0 & 68.0 & 551 & 5.3 \\
\hline
\end{tabular}




\subsection{Variáveis analisadas}

3.7.1 Ramulose nos sistemas de semeadura e evolução da doença nos tratamentos

O desenvolvimento e evolução da doença foi avaliado periodicamente, por meio escala de notas, descrita na Tabela 8. As notas foram dadas em cada planta das duas linhas centrais de cada subparcela, considerando os sintomas em toda a planta, no total de 7 avaliações da doença, distribuídas entre as fases fenológicas do algodoeiro, como especificado na Tabela 9

Tabela 8. Escala de notas para avaliação da Ramulose do algodoeiro

\begin{tabular}{cl}
\hline Nota & \multicolumn{1}{c}{ Sintoma visível } \\
\hline 1 & Planta sem sintomas visíveis \\
2 & Planta com manchas estreladas nas folhas do ponteiro \\
3 & Plantas com redução nos internódios do ponteiro e manchas nas folhas \\
4 & Planta com superbrotamento, com pouca diminuição no crescimento \\
5 & Planta com superbrotamento e com desenvolvimento e porte reduzido \\
\hline
\end{tabular}

Fonte: Cia et al 1982.

Tabela 9. Datas das avaliações realizadas nas parcelas experimentais e correlação com a fase fenológica da cultura. Ano agrícola 2002/03. Piracicaba, SP

\begin{tabular}{cccc} 
Avaliação & Data avaliação & DAE & Fase fenológica \\
\hline 1 & $03 / 02 / 03$ & 58 & $\mathrm{R} 3$ \\
2 & $21 / 02 / 03$ & 77 & $\mathrm{R} 5$ \\
3 & $02 / 03 / 03$ & 85 & $\mathrm{R} 6$ \\
4 & $17 / 03 / 03$ & 100 & $\mathrm{R} 6$ \\
5 & $08 / 04 / 03$ & 122 & $\mathrm{R} 7$ \\
6 & $20 / 04 / 03$ & 134 & $\mathrm{R} 8$ \\
7 & $04 / 05 / 03$ & 148 & $\mathrm{R} 8$ \\
\hline
\end{tabular}

Não foram mantidos intervalos regulares de avaliação devido à ocorrência de chuvas entre os períodos. 


\subsubsection{Produção de algodão em caroço e produtividade}

Após a colheita, o peso total da produção das parcelas foi computado, e verificada a correlação entre a os sistemas de semeadura e a produção final e a produção por área de algodão em caroço.

\subsubsection{Caracteres agronômicos de laboratório}

A partir da amostra de 20 capulhos de cada subparcela experimental foram determinadas:

a) massa de 100 sementes - massa média, em gramas, de 100 sementes;

b) porcentagem de fibra - a porcentagem de fibra foi determinada por diferença a partir da massa das sementes (g), expressa em porcentagem;

c) massa média de um capulho - correspondendo à média da massa dos capulhos, em gramas.

\subsubsection{Características tecnológicas da fibra}

Nas amostras de 20 capulhos, colhidos no terço médio das plantas em cada parcela experimental, foram realizados através do equipamento HVI (High Volume Instrument) da Zellweger Uster/Spinlab série 900 da Agência Paulista de Tecnologias dos Agronegócios (Instituto Agronômico de Campinas, centro experimental central):

a) comprimento da fibra: valor médio, em milímetros, do comprimento "span 2,5\%", obtido a partir de cinco determinações feitas em cada amostra; 
b) uniformidade de comprimento: valor médio, expresso em porcentagem, da uniformidade do comprimento das fibras, baseado na relação dos valores de comprimento "span 50\%" e "span 2,5\%", obtido a partir de cinco determinações feitas em cada amostra;

c) micronaire: índice que representa a finura da fibra, quando são iguais as condições de maturidade. Em nosso meio representa mais comumente o complexo finura + maturidade, quando ambas as propriedades variam. É obtido mediante duas determinações em cada amostra;

d) tenacidade: índice médio referente à resistência à tração de uma mecha de fibras, expresso em g.Tex ${ }^{-1}$, obtido mediante quatro determinações em cada amostra;

e) maturidade: valor médio referente à porcentagem de fibras maduras, obtido a partir de cinco determinações feitas na amostra;

f) tenacidade do fio: valor médio, determinado no dinamômetro Dynamat II, da resistência do fio singelo, de título inglês $\mathrm{Ne} 22$, expresso em RKM e obtido mediante vinte arrebentamentos em cada amostra; 


\section{RESULTADOS E DISCUSSÃO}

4.1 Ramulose nos sistemas de semeadura e evolução da doença nos tratamentos

\subsubsection{Ramulose nos sistemas de semeadura}

Pode-se observar pelas médias de notas na Tabela 10, ao compararmos as médias em relação ao sistema de semeadura (com palhada e convencional), que não houve diferença significativa para ambos tratamentos para cada avaliação realizada.

$\mathrm{Na}$ Figura 5 há uma comparação gráfica ilustrativa entre os sistemas de semeadura com palha e convencional para a cultivar resistente `a Ramulose IAC 23 (Tratamentos com palha e convencional)

A doença se desenvolveu na cultivar resistente provavelmente devido à alta pressão de inóculo aplicada, associada às condições meteorológicas consideradas ótimas para o desenvolvimento da doença, como pode ser observado nas Tabelas 6, 7 e 11, citadas anteriormente. Segundo Santos et al. (1994), temperaturas entre 25 e $30^{\circ} \mathrm{C}$ e altas precipitações, são favoráveis ao desenvolvimento da doença.

A Ramulose, na cultivar IAC 23, ocorreu com menor intensidade no tratamento com palha, em relação ao tratamento sem palha, porém, não resultando em diferença significativa, de modo que a resistência da cultivar se sobressai aos tratamentos com e sem palha. 
Tabela 10. Notas médias atribuídas aos sintomas de Ramulose nas plantas nos tratamentos inoculados. Ano agrícola 2003/03. Piracicaba, SP

\begin{tabular}{cccccccc}
\hline & & \multicolumn{7}{c}{ DAE } \\
Tratamento & 58 & 77 & 85 & 100 & 122 & 134 & 148 \\
\hline Cult. Resistente, com palha & $2,3 \mathrm{~b}$ & $2,5 \mathrm{~b}$ & $2,6 \mathrm{~b}$ & $2,8 \mathrm{~b}$ & $2,4 \mathrm{c}$ & $2,4 \mathrm{c}$ & $2,4 \mathrm{c}$ \\
Cultivar suscetível, com palha & $2,1 \mathrm{~b}$ & $2,7 \mathrm{~b}$ & $2,9 \mathrm{~b}$ & $3,0 \mathrm{~b}$ & $3,4 \mathrm{~b}$ & $3,3 \mathrm{~b}$ & $3,3 \mathrm{~b}$ \\
Cultivar resistente, sem palha & $2,4 \mathrm{~b}$ & $2,5 \mathrm{~b}$ & $2,7 \mathrm{~b}$ & $2,9 \mathrm{~b}$ & $2,6 \mathrm{bc}$ & $2,6 \mathrm{bc}$ & $2,6 \mathrm{bc}$ \\
Cult suscetível, sem palha & $3,3 \mathrm{a}$ & $3,8 \mathrm{a}$ & $3,9 \mathrm{a}$ & $4,0 \mathrm{a}$ & $4,1 \mathrm{a}$ & $4,1 \mathrm{a}$ & $4,1^{\mathrm{a}}$ \\
CV\% & 17,85 & 15,1 & 13,2 & 11,7 & 15,41 & 16,32 & 16,32 \\
\hline
\end{tabular}

Os valores seguidos pela mesma letra na coluna não diferem estatisticamente entre si, ao nível de $5 \%$ de probabilidade, pelo teste de Tukey.

$\square$ Cultivar resistente, inoculada, com palha

- Cultivar resistente, inoculada, sem palha

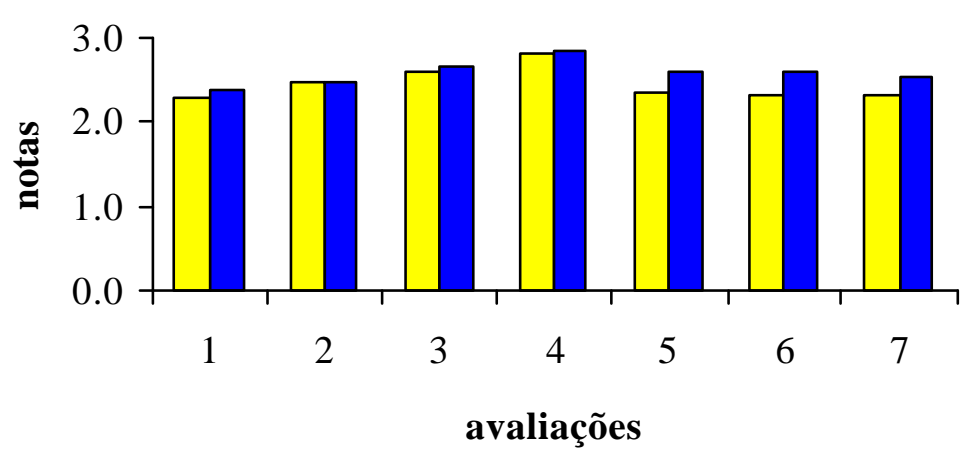

Figura 5- Comparação estatística das médias de notas para a cultivar resistente IAC 23 em relação ao sistema de semeadura em todas as avaliações. Ano agrícola 2002/03. Piracicaba, SP

Nas testemunhas não inoculadas não ocorreu evolução da doença, independente da cultivar, comprovando que não havia inóculo no campo antes da inoculação. Não foi observada também a disseminação da doença no campo, provavelmente porque até que aparecessem os primeiros sintomas nas plantas inoculadas, a doença esteve em período 
latente, por aproximadamente 7 dias. Santos et al. (1994), observaram que para que se manifestassem os primeiros sintomas nas plantas, em seu estudo sobre progresso e gradiente da Ramulose na cultivar IAC 20, segundo Bergamin Filho \& Amorin (1996), em período latente a doença ainda não tem capacidade de infectar outras plantas (Bergamin Filho \& Amorin, 1996). Quando os sintomas começaram a aparecer, é possível que as plantas adjacentes sadias já não estivessem em um estádio de alta prédisposição à doença, o que ocorreu em 15 de janeiro, aos 41 DAE. Nesta fase, de acordo com o trabalho de Santos at al. (1993), a possibilidade de ocorrência de plantas doentes é de aproximadamente 56,6\%, em caso de inoculação, onde a pressão de inóculo é muito alta, além disso. Este período coincidiu também com condições meteorológicas impróprias desfavoráveis à doença, com temperaturas elevadas, ausência de chuvas e umidade relativa baixa, ao redor de $86 \%$.

Para a cultivar suscetível Makina, observa-se na Tabela 10 e ilustrativamente na Figura 6 que houve diferença estatística significativa entre o sistema de semeadura com palhada e convencional, sendo que as médias das notas no tratamento com semeadura convencional foram mais altas do que na palhada, mostrando que neste caso, a presença da palha influenciou no desenvolvimento da doença.

A diferença observada pode ter ocorrido porque, além da cultivar Makina ser altamente suscetível à doença, as condições macroclimáticas ocorridas no período foram favoráveis ao desenvolvimento da doença (temperaturas entre 25 e $30^{\circ} \mathrm{C}$, alta precipitação e umidade relativa, Figuras de 9 a 15) no tratamento com semeadura convencional. Para o tratamento com palha, além das condições macroclimáticas favoráveis associadas à suscetibilidade desta cultivar à doença, como na semeadura convencional, ainda há o agravante de que a presença da palhada, por si só, pode causar o aumento da umidade relativa sob o dossel, e consequente aumento da duração do período de molhamento foliar, como já relatado pr Rotem (1978). A presença da palha pode causar também diminuição da amplitude térmica, também constatado por Monteiro (2002), que encontrou diferenças entre a temperatura do ar e a da superfície vegetada, onde nesta última se atribuíram valores mais baixos. 
$\square$ cultivar suscetível, inoculada, com palha

口ultivar suscetível, inoculada, sem palha

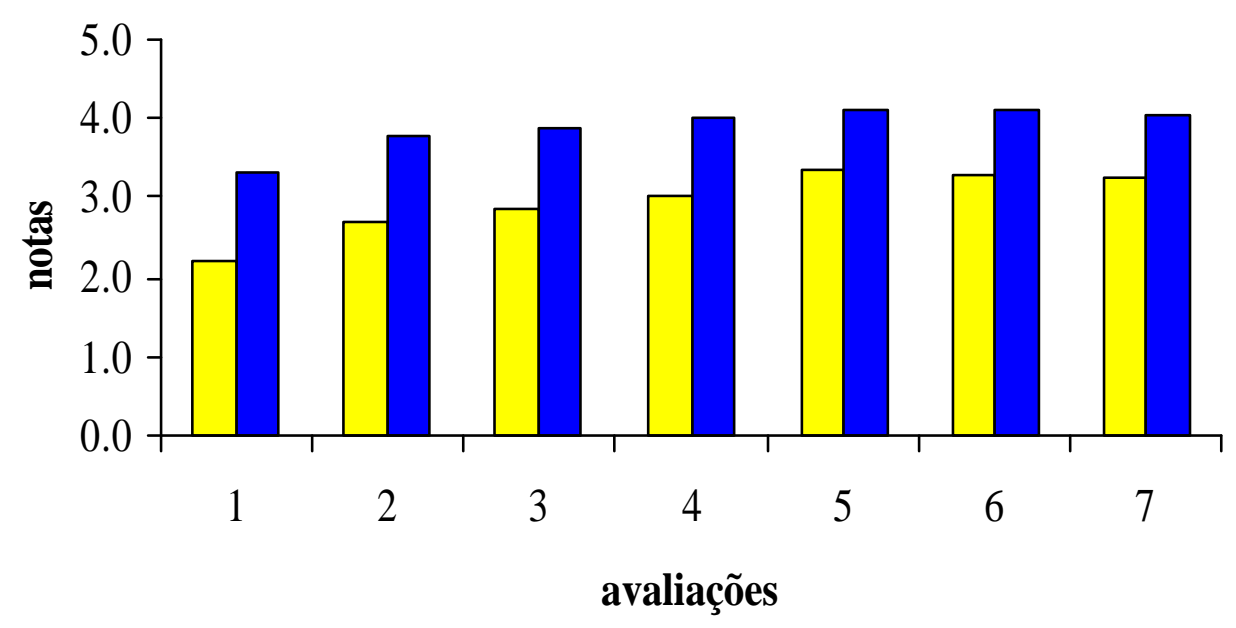

Figura 6- Comparação estatística das médias de notas para a cultivar resistente suscetível

(Makina) em relação ao sistema de semeadura, em todas as avaliações. Ano agrícola 2002/03. Piracicaba, SP

Em sistemas com utilização de resíduos em superfícee, há modificação das condições de temperatura nas camadas superficiais do solo, como foi comprovado por Gupta et al. (1984). Estes autores estudaram a temperatura e fluxo de calor no solo em 4 profundidades em diferentes condições de preparo do solo e palhada na superfície, e encontraram que na superfície do solo $(0 \mathrm{~m})$, sem preparo e sem resíduos, a temperatura no horário mais quente do dia chegou a $40^{\circ} \mathrm{C}$ e $7^{\circ} \mathrm{C}$ no horário mais frio, resultando em amplitude térmica de $33^{\circ}$ C. No tratamento sem preparo do solo e palha, a temperatura máxima chegou a $26^{\circ} \mathrm{C}$ aproximadamente, e a mínima a $6 \mathrm{C}$, resultando em $20^{\circ} \mathrm{C}$ de amplitude térmica. Em solo arado, com palhada, sistema muito utilizado em regiões do Mato Grosso, a temperatura máxima chegou a $31^{\circ} \mathrm{C}$, e a mínima a $5^{\circ} \mathrm{C}$, numa amplitude total de $26^{\circ}$ C. O tratamento sem preparo com palha é o mais próximo de sistema de plantio direto, onde a temperatura mais alta foi inferior às dos demais tratamentos, e a amplitude térmica foi bem menor. Assim, podemos inferir que a utilização da palha diminuiu em $13^{\circ} \mathrm{C}$ a amplitude térmica, demonstrando que a palhada é muito importante 
no processo de isolamento térmico entre o ar logo acima da superfície. O preparo do solo com arado e palha foi o que mais se aproximou das condições do presente estudo, resultando em amplitude térmica de $26^{\circ} \mathrm{C}$.

No mês de janeiro, após a inoculação, a Umidade Relativa média foi de $92 \%$, considerada favorável ao desenvolvimento da doença. Porém, a temperatura máxima média observada durante este mês foi de $29,6^{\circ} \mathrm{C}$ e a média das mínimas foi de 20,2, resultando em amplitude térmica média de $9,4^{\circ} \mathrm{C}$. Considerando apenas a variável temperatura, pode-se inferir que as condições térmicas foram boas para o desenvolvimento da doença, porém, em presença de palha, as temperaturas se amenizam sob o dossel das plantas de algodoeiro, diminuindo ainda mais a amplitude térmica, fazendo com que a temperatura seja a variável limitante para maior ocorrência de doença nestas condições.

Em regiões tropicais e subtropicais Agrios (1997) encontrou que as condições de umidade exerceram papel limitante em seus estudos avaliando o efeito do ambiente no desenvolvimento de doenças, mas ainda em 1978, Rotem, estudando o efeito do clima e do tempo no desenvolvimento de epidemias, constatou que quando as condições de temperatura são diferentes do ótimo para o desenvolvimento da doença, a taxa de crescimento pode se reduzir, ocorrendo decréscimo no número de infecções e diminuição do inóculo, modificando a duração do período de germinação de esporos, penetração, colonização e reprodução, afetando a velocidade de reprodução e quantidade de propágulos, dados estes que concordam com os de Bedendo (1995).

Santos et al. (1994), quando estudaram as condições de ocorrência para o progresso e gradiente da Ramulose afirmaram que as variáveis que mais se correlacionaram com a ocorrência da doença foram a precipitação e a média das temperaturas mínimas diárias, onde não se observou progresso de doença quando as chuvas cessaram e a média da temperatura mínima foi de $12,8^{\circ} \mathrm{C}$.

Ainda com relação à presença da palhada, verifica-se que também causa aumento da reflectância, o que colabora na diminuição da temperatura sob o dossel, como já comprovado por Adams (1960); Fowler \& Rockstrom (2001) e Benoit \& Lindstron (1987), que encontraram aumento da reflectância com utilização de palhada, com 
menores valores de radiação líquida que atingiu a superfície, o que resultou em menores temperaturas no solo, afetando sobremaneira e diferenciando as condições microclimáticas sob o dossel.

Essa diferença de temperatura entre o ar logo acima do dossel e do ar sob o dossel já foi constatados e estudados por Gassen \& Gassen (1996) em seus estudos sobre Plantio Direto, e mais recentemente por Monteiro (2002), que estudou as condições microclimáticas da cultura do algodoeiro sob diferentes densidades populacionais, e encontrou que as diferentes densidades não apresentam diferenças de temperatura a partir dos $45 \mathrm{DAE}$, porém, houve diferença entre a temperatura no terço superior das plantas e a temperatura medida na estação meteorológica no centro da área experimental.

Pereira et al, (2002) também afirmam que o tipo de cobertura do solo influencia no balanço de energia local, intensificando o efeito microclimático, tanto no aquecimento diurno como no resfriamento noturno, resultando em diminuição da amplitude térmica.

Como se trata do primeiro ano de experimentação, estes resultados são ainda pouco consistentes, e o que se pretende com a continuidade do ensaio, mantendo o solo com os restos de cultura, é verificar se o patógeno permanecerá no campo nos restos de cultura até o ano seguinte, através de suas estruturas de resistência (ascósporos), como afirmam Kimati et al. (1997), a fim de avaliarmos se a infecção vai ocorrer igualmente para os tratamentos com e sem palhada. Machado (1988), encontrou viabilidade em micélio dormente do patógeno por até 13 anos, em condições desfavoráveis para o desenvolvimento da doença.

No próximo ano, com a permanência da palhada no sistema, pode-se esperar alterações nos resultados, com o agravante de que há competição interespecífica na microfauna do solo, como afirmam Gassen \& Gassen (1996), que estudaram o manejo de doenças em sistemas de plantio direto e observaram que a palhada proporciona aumento na atividade de microorganismos decompositores e fitopatógenos. Porém, esse aumento é significativo quando são cultivadas sucessivamente plantas hospedeiras das mesmas doenças, diferentemente do que pode correr pelo uso de diferentes coberturas e rotação de culturas, resultando no controle natural de microorganismos patogênicos. 
Os mesmos autores afirmam também que praticamente todas as doenças que ocorrem no sistema convencional, podem ocorrer no plantio direto, porém, as diferenças maiores ocorrem em função da atividade microbiana maior no plantio direto, resultando no controle biológico natural de patógenos de plantas. Entretanto, neste trabalho não foi possível constatar tal afirmação.

Em relação à ocorrência da doença em sistemas com presença de restos de cultura, os estudos existentes referem-se principalmente ao tombamento de plântulas, que são de ocorrência generalizada nas área produtoras de algodão. Batson \& Caceres (2000) fizeram um estudo ao longo de dez anos entre o sistema de preparo reduzido e convencional de algodoeiro e encontraram os mesmos resultados experimentais que Gridi-Papp et al. (1992) e Cia \& Salgado (1997), nas nossas condições, mostrando que a palhada proporciona o aumento da incidência de tombamento de plântulas.

\subsubsection{Evolução da Ramulose nos tratamentos}

As curvas de evolução da doença encontram-se na Figura 7A. Pode ser observado que os maiores incrementos e evolução da doença ocorreram a partir da inoculação, realizada aos $34 \mathrm{DAE}$, em todos os tratamentos, principalmente devido à alta pressão de inóculo, associada às condições meteorológicas favoráveis. Para a cultivar suscetível em semeadura convencional o crescimento da doença ocorreu de forma mais intensa, alcançando médias de notas de sintomas superiores no mesmo intervalo. Nota-se neste período que suscede a inoculação, no mês de janeiro, através das figuras $7 \mathrm{~B}$ e $7 \mathrm{C}$, que as condições de temperatura, umidade e precipitação foram consideradas ótimas para o processo infeccioso da Ramulose, tanto é que não foram necessárias mais que uma inoculação, como comentado no ítem 3.6.3., uma vez que seriam feitas 2 ou mais inoculações se necessário para o estabelecimento da doença. Santos et al. (1994) afirmam que condições ótimas para o desenvolvimento da doença são temperaturas entre 25 e $30^{\circ} \mathrm{C}$ e alta umidade relativa. 
$\multimap$ Cultivar resistente, inoculado, com palha $\longrightarrow$ Cultivar suscetível, inoculado, com palha $\rightarrow$ Cultivar resistente, inoculado, sem palha $\rightarrow$ Cultivar suscetível, inoculado, sem palha
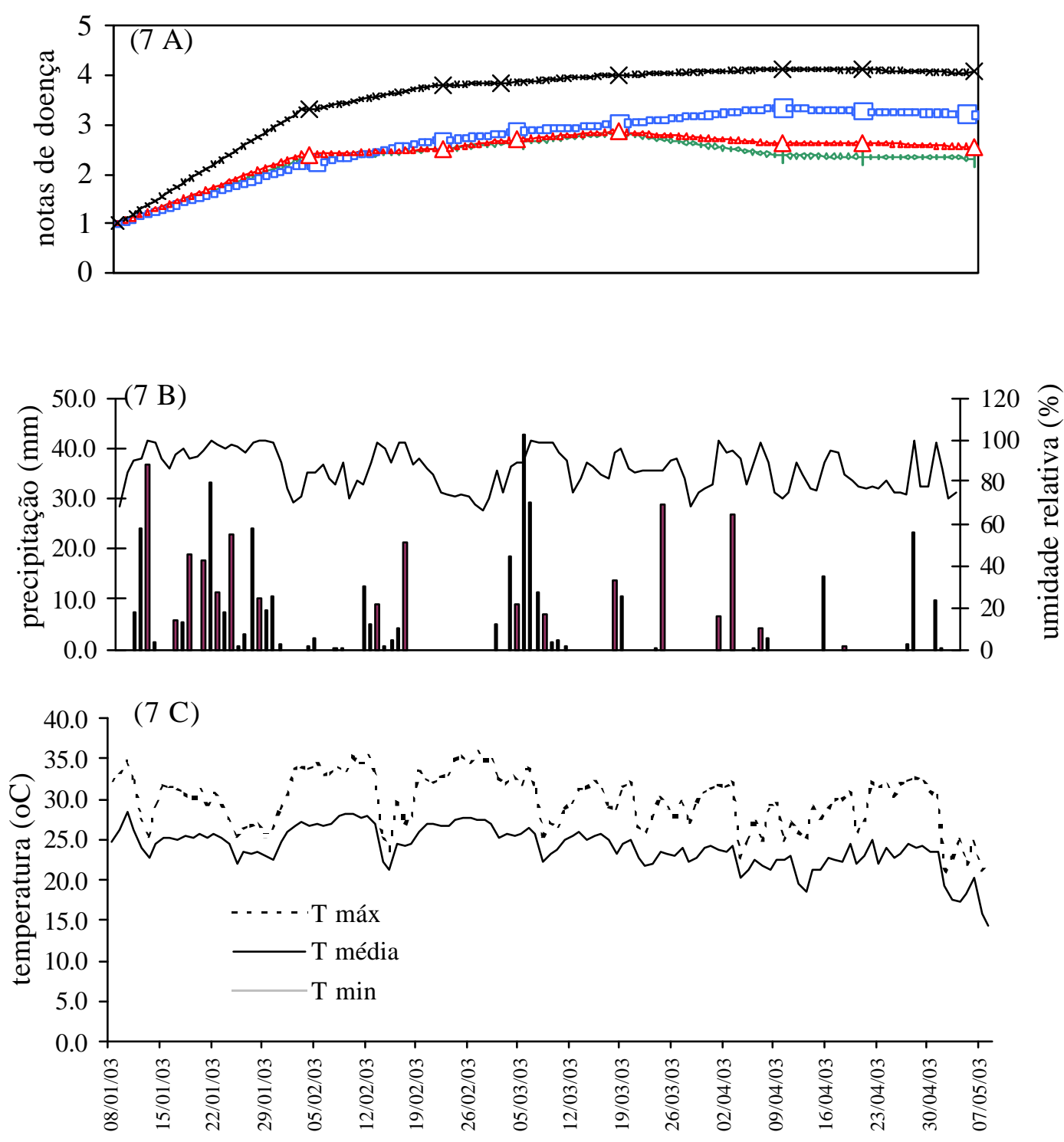

Figura 7- Evolução da doença nos tratamentos (7A); precipitação e umidade relativa no período de condução (7B) e temperaturas máxima, média e mínima no período de condução (7C). Ano agrícola 2002/03. Piracicaba, SP 
Os períodos de maior suscetibilidade das plantas de algodão ao ataque do patógeno, de acordo com Santos et al (1993), são de 25, 35 e 45 DAE, em ordem decrescente de pré-disposição à doença, e a data de inoculação do patógeno nos tratamentos ocorreu no dia 8 de janeiro, aos 34 DAE, estando, portanto situada entre os dois períodos de maior suscetibilidade do hospedeiro ao patógeno. Neste estudo de Santos et al. (1993), foi observado a inoculação aos 35 DAE há possibilidade de índice de doença de aproximadamente $60 \%$. No nosso caso, associando às condições meteorológicas extremamente favoráveis ao desenvolvimento do patógeno no mês de janeiro, como pode ser observado na Tabela 11, favoreceram o desenvolvimento do patógeno e infecção das plantas.

Tabela 11. Condições meteorológicas dos 3 meses seguintes àinoculação da doença. Ano agrícola 2002/03. Piracicaba, SP

\begin{tabular}{ccccccc} 
Meses & T máx & $\begin{array}{c}\text { T mín } \\
\text { oC }\end{array}$ & T média & $\begin{array}{c}\text { Precipitação } \\
\mathrm{mm}\end{array}$ & $\begin{array}{c}\text { Umid. Relativa } \\
\%\end{array}$ & $\begin{array}{c}\text { Vento médio } \\
\mathrm{km} / \text { hora }\end{array}$ \\
\hline Janeiro & 29,6 & 20,2 & 24,9 & 302,4 & 92 & 6,6 \\
Fevereiro & 32,5 & 20,4 & 26,5 & 58,6 & 83 & 5,7 \\
Marco & 30 & 18,6 & 24,3 & 180,9 & 86 & 6,8 \\
\hline
\end{tabular}

Ainda em relação à figura $7 \mathrm{~A}$, na primeira avaliação, ocorrida em 03 de fevereiro, aos 58 DAE, observa-se a diferença entre o tratamento com a cultivar suscetível na semeadura convencional e os demais. Com exceção deste tratamento, foi possível distinguir diferenças entre os demais tratamentos, e o que pode ser observado a partir deste período é que para cada tratamento isoladamente não houve crescimento significativo da doença, a não ser para o tratamento com cultivar suscetível e semeadura convencional, até os 77 DAE, data da segunda avaliação (21 de fevereiro), mantendo-se ainda a diferença entre este tratamento e os demais.

Este período de estabilidade da doença pode ter ocorrido devido às condições meteorológicas menos favoráveis ao desenvolvimento do patógeno no mês de fevereiro, como pode ser observado na Tabela 11, com baixa precipitação pluvial e baixa umidade relativa, mantendo então níveis estáveis do inóculo no campo. Observa-se também, na 
Figura 16, no ítem 4.2.6 que a insolação neste período esteve acima da média normal de 10 anos, o que pode ter afetado a duração do período de molhamento, variável de extrema importância no processo epidemiológico. O pequeno incremento na evolução da doença na cultivar suscetível, com semeadura convencional, pode ser explicado com base na alta suscetibilidade desta cultivar, onde verifica-se que mesmo em condições pouco favoráveis, a doença continuou evoluindo.

No período entre a segunda e a terceira avaliação, realizada em 02 de março, aos 85 DAE, não se constata evolução da doença, período este no qual se observa na Figura 7B a ausência de precipitação pluvial, e consequente queda da umidade relativa, acompanhada de altas temperaturas neste período (Figura 7C), proporcionando condições abaixo das requeridas pelo patógeno. Santos et al. (1993) constataram, ao avaliar o progresso e gradiente da Ramulose, que aos 81 DAE houve maior aumento da doença no campo, porém, as condições meteorológicas neste experimento foram extremamente favoráveis, com umidade relativa superior à $90 \%$ e temperatura mínima de $18^{\circ} \mathrm{C}$. Podemos inferir, através destas informações que de fato são as condições meteorológicas no local que determinam o crescimento e evolução da doença. Rotem (1988) afirma que ao associarmos uma condição diferente da usual, como alguma técnica que altere o microclima no interior do dossel (Rotem, 1988), vai influenciar no comportamento do patossistema.

A partir do período de $85 \mathrm{DAE}$, a doença continuou crescendo, favorecida pela ocorrência de melhores condições meteorológicas até os 100 DAE, data da quarta avaliação da doença no campo, onde observa-se que o crescimento se deu em todos os tratamentos, mantendo-se as diferenças, porém, com pequeno incremento.

A partir dos 100 DAE, a doença no tratamento com a cultivar suscetível e palhada retoma o crescimento, diferenciando-se dos demais, e no tratamento com a cultivar suscetível convencional continua estável, com médias altas de doença, enquanto que nos tratamentos com a cultivar resistente, independente do sistema de semeadura, a doença decresce. Observa-se que as condições meteorológicas neste período são consideradas pouco favoráveis ao desenvolvimento do patógeno, com períodos suscessivos de baixa umidade relativa, e decréscimo da temperatura. 
Ocorre que devido à alta susceptibilidade da cultivar Makina, mesmo sob condições menos favoráveis ao desenvolvimento do patógeno, a doença pode continuar evoluindo, aproveitando-se dos curtos períodos favoráveis, que ocorreram neste mês, nos dias 20, 21 e 27 de março, com ocorrência de pouca chuva e os dias de chuva acompanhados de um aumento na umidade relativa.

Estas condições meteorológicas menos favoráveis, no caso da cultivar resistente IAC 23, contrariamente ao que ocorreu para a cultivar suscetível Makina, já foram suficientes para o decréscimo da doença no campo, nos tratamentos com esta cultivar, como era de se esperar, já que esta cultivar apresenta resistência genética, e neste período era reduzida a pressão de inóculo.

Com as avaliações, as média dos sintomas da doença no campo podem decrescer. Isto ocorre devido à não disseminação da doença para as brotações novas na planta, associadas às condições meteorológicas desfavoráveis ao patógeno, reduzindo ainda mais o aparecimento de sintomas da doença na cultivar resistente.

A partir dos 122 DAE, não se observa mais evolução da doença nos tratamentos, período este (março, abril e maio), que coincide com condições menos favoráveis ao patógeno, como ocorreu nos estudos de Santos et al. (1994), sobre gradiente da Ramulose em algodoeiro, na cultivar IAC 20, que também observaram paralização da doença a partir deste período.

De um modo geral, nos tratamentos com a cultivar suscetível, o desenvolvimento da doença continuou estável, mesmo sob condições meteorológicas menos propícias (temperatura, precipitação pluvial e umidade relativa, Figuras 7A, 7 e 7C). Isto ocorre devido à alta pré-disposição da cultivar suscetível à doença, onde mesmo sob mesmas condições de pressão de inóculo na área, observou-se maiores médias. Não se verificou na cultivar Makina o mesmo potencial para continuação do desenvolvimento vegetativo que ocorreu cultivar IAC 23, que sob condições meteorológicas menos propícias ao patógeno, retomou o desenvolvimento vegetativo, obtendo melhor desempenho reprodutivo e escape da doença.

Na Figura 8 pode-se observar o comportamento das cultivares em relação à evolução da doença, sem considerar o sistema de semeadura. Nota-se que a cultivar 
suscetível Makina apresenta maior crescimento inicial da doença, mantendo-se em crescimento até que sob condições meteorológicas menos propícias, permanece constante. Na cultivar resistente o crescimento inicial da doença é menor, com médias inferiores em todos os períodos, diminuindo ainda mais a partir do momento em que as condições meteorológicas não são favoráveis.

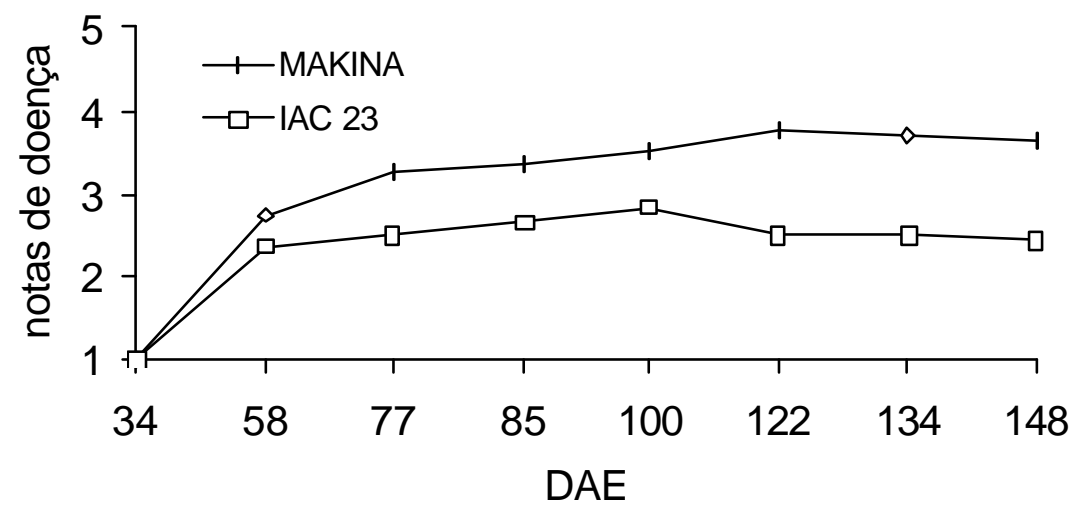

Figura 8- Evolução da Ramulose para as cultivares resistente (IAC 23) e suscetível (Makina). Ano Agrícola 2002/03. Piracicaba, SP

Deve-se ressaltar que o experimento foi avaliado no primeiro ano, porisso a palhada pode não ter tido uma importância muito significativa, não podendo certificar se a permanência dos restos de cultura nos próximos anos de condução influenciariam na evolução da doença.

4.2 Análise das condições meteorológicas

A fim de verificarmos se durante o período de experimentação as condições meteorológicas foram normais, foram medidas através de estação meteorológica as variáveis temperatura máxima, mínima e média, radiação global, umidade relativa, velocidade média do vento, insolação diária e precipitação pluvial (Figuras 9 a 16). 
Esses dados foram comparados com a média dos últimos 10 anos para cada variável, na mesma estação meteorológica.

As condições meteorológicas do local, ou, as condições macroclimáticas são importantes por estarem diretamente relacionadas com as condições de ocorrência de doenças foliares no campo, de acordo com Pedro Jr. (1989).

\subsubsection{Temperatura}

Conforme podemos observar nas Figuras 9, 10 e 11, para as medidas de temperatura efetuadas ao longo do ciclo da cultura, não houveram discrepâncias entre o período estudado e as médias de 10 anos. As temperaturas seguiram as tendências normais para os meses em questão. Para o desenvolvimento da Ramulose, considera-se que as condições de temperatura média (considerada isoladamente) entre 25 e $30^{\circ} \mathrm{C}$ foram adequadas.

As condições de temperatura são muito importantes no desenvolvimento de epidemias, uma vez que afetam diretamente a taxa de crescimento da doença, pela modificação da duração do período de molhamento foliar, afetando a germinação de esporos, penetração, colonização e reprodução, modificando a velocidade de reprodução e quantidade de propágulos. (Rotem, 1978 e Bedendo, 1995).

No presente estudo, as condições de temperatura foram primordiais para se estudar o desenvolvimento da doença, pois a presença de resíduos afeta a temperatura na superfície do solo afetam sua temperatura, como observado por diversos autores (Adams, 1960; Benoit \& Lindstrom, 1987; Fowler \& Rockstrom, 2001), modificando a temperatura sob o dossel das plantas, concordando com os resultados de estudos realizados por Gupta et al. (1984). 


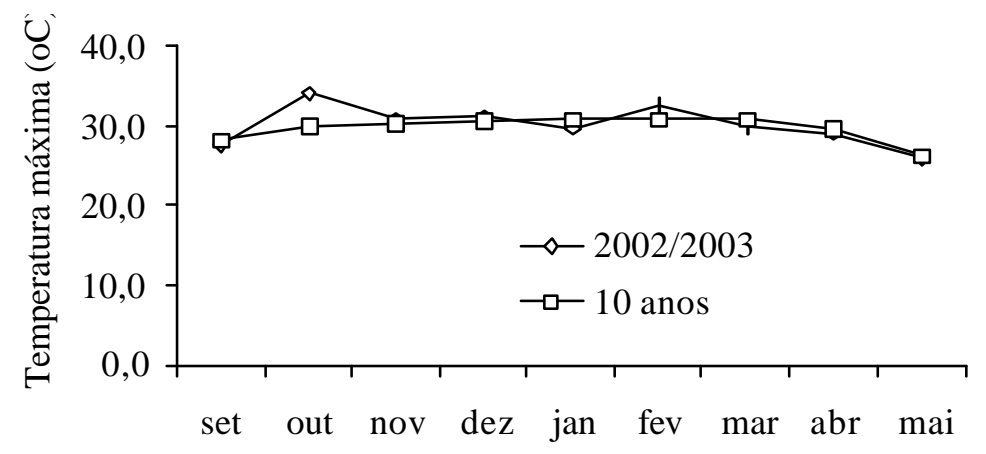

Figura 9- Comparação de medidas de temperatura máxima do período estudado em 2003/03 e dados médios de 10 anos. Piracicaba, SP

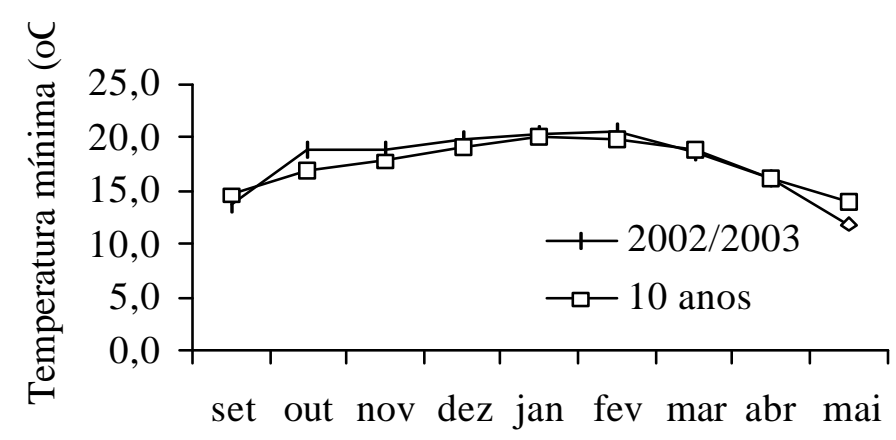

Figura 10- Comparação de medidas de temperatura mínima do período estudado com dados médios de 10 anos. Piracicaba, SP

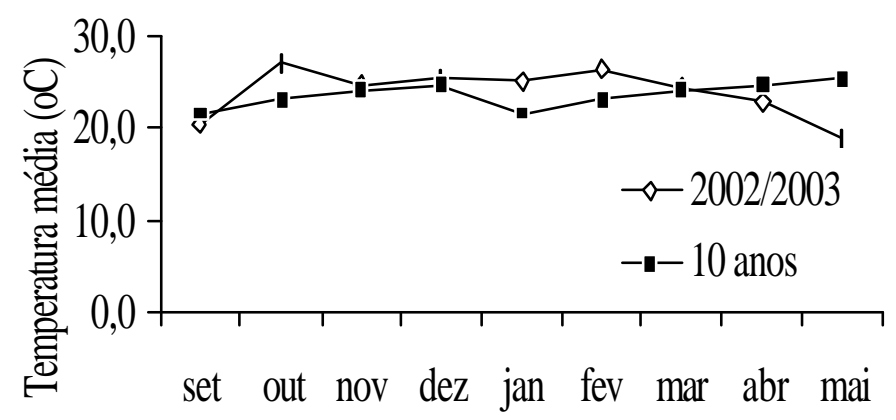

Figura 11- Comparação de medidas de temperatura média $\left({ }^{\circ} \mathrm{C}\right)$ do período estudado em 2003/03 e dados médios de 10 anos. Piracicaba, SP 


\subsubsection{Umidade Relativa}

Quanto à umidade relativa do ar (Figura 12), no período em questão observa-se que houve discrepância em relação à média de 10 anos, apenas para o mês de outubro, quando ainda não havia o hospedeiro (algodoeiro) e nem patógeno no campo. Para o mês de janeiro, mês da inoculação do patógeno, as condições de umidade relativa foram boas e mantiveram-se acima da média, caindo posteriormente nos meses seguintes. Cabe ressaltar que as condições de umidade relativa estão diretamente relacionadas à duração do período de molhamento foliar (DPM), variável de extrema importância no processo infeccioso das doenças, incluindo a Ramulose. (Rotem, 1978). A DPM é determinada pela película de água que fica na superfície das folhas, devido à ocorrência de orvalho, chuva ou irrigação, e é uma variável extremamente importante no processo infeccioso. (Rotem, 1978).

Agrios (1997) constatou que em regiões tropicais e subtropicais, as condições de umidade exercem papel limitante no desenvolvimento de epidemias.

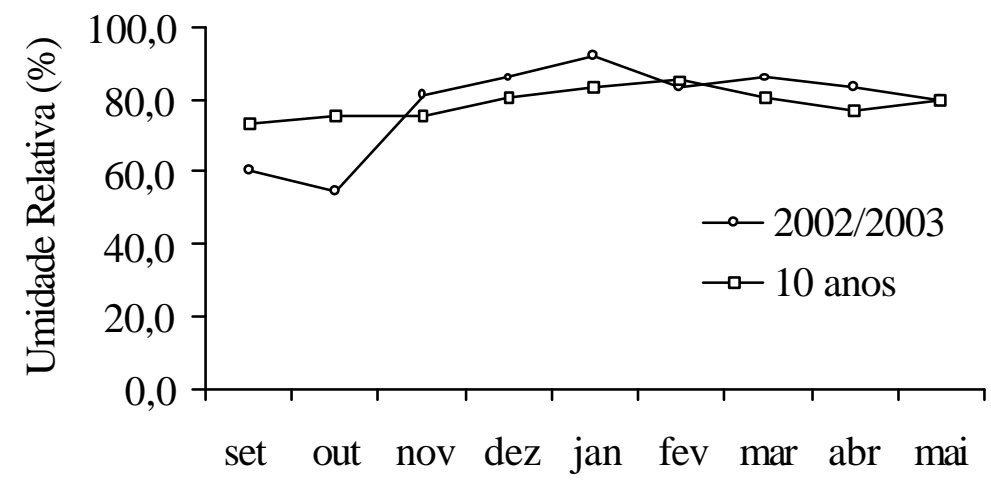

Figura 12- Comparação de medidas de Umidade relativa média (\%) do período estudado em 2003/03 e dados médios de 10 anos. Piracicaba, SP 


\subsubsection{Precipitação Pluvial}

Os dados de precipitação pluvial presentes na Figura 13, indicam que o período em questão foi extremamente atípico nos meses de janeiro e fevereiro, não seguindo a normal de 10 anos de medidas. Pode-se observar que no mês de fevereiro, a quantidade de chuvas foi quatro vezes menor do que a normal para este mês, voltando a se igualar no mês de março, abril e maio. Como já foi visto no ítem 4.1.1, que se refere à ocorrência da doença nos tratamentos, este dado é de extrema importância para explicar a não ocorrência de disseminação da Ramulose na área experimental nas testemunhas não inoculadas com o patógeno.

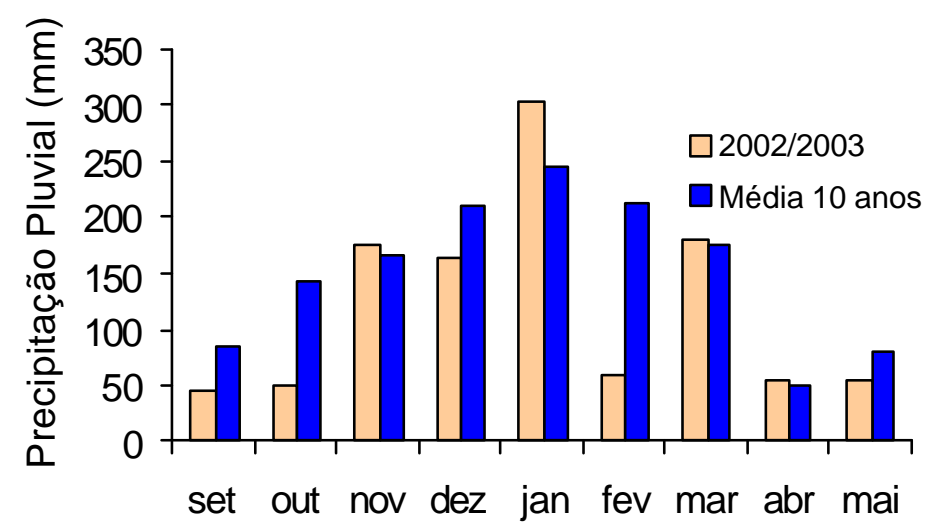

Figura 13- Comparação de medidas de Precipitação pluvial (mm) do período estudado em 2003/03 e dados médios de 10 anos. Piracicaba, SP 


\subsubsection{Radiação Solar}

Observa-se através da Figura 14, que no período de experimentação, as médias de Radiação Solar seguiram as médias normais em praticamente todos os meses, havendo uma pequena discrepância no mês de janeiro, onde a média foi um pouco menor, e no mês de fevereiro, quando a média esteve num patamar um pouco acima.

A radiação solar líquida quando se utiliza palhada sobre a superfície do solo é uma variável importante por interferir nas mudanças microclimáticas, como observado por Benoit \& Lindstron (1987), que constataram que o aumento da reflectância com utilização de palhada resulta em menor radiação líquida que atinge a superfície, aumento da reflectância, ocorrendo, consequentemente diminuição da temperatura, variável que interferem no desenvolvimento de doenças.

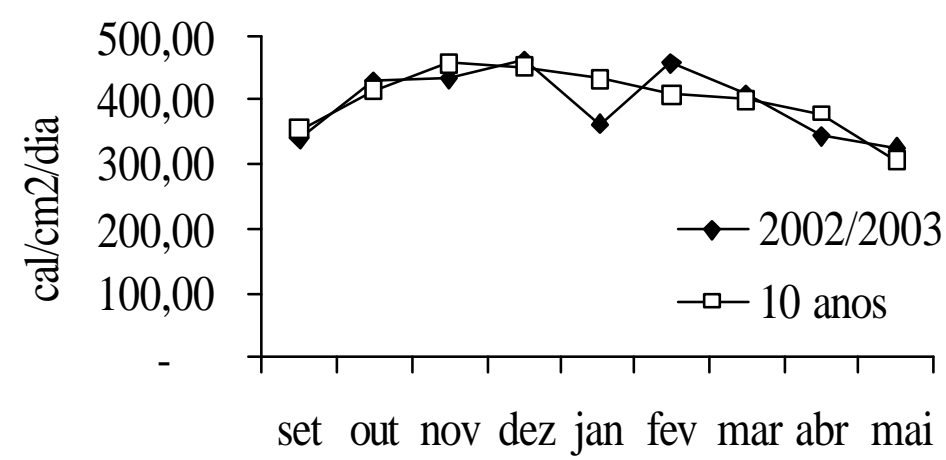

Figura 14- Comparação de medidas de Radiação Solar (cal/cm/dia) do período estudado em 2003/03 e dados médios de 10 anos. Piracicaba, SP 
4.2.5 Velocidade média do vento

Comparando-se as médias de velocidade média do vento, presentes na Figura 15 podemos inferir que o período de experimentação foi típico, seguindo as tendências normais das medidas de 10 anos, havendo apenas uma pequena diferença nos meses de fevereiro e abril, onde a velocidade do vento manteve-se um pouco abaixo do normal para estes períodos. A baixa velocidade do vento ocorrida no mês de fevereiro é uma variável importante e foi abordado no ítem 4.1.1, relacionando à pouca ou nula disseminação do patógeno no campo, que segundo Lenné (1984) ocorre tanto através de conídios produzidos em conidióforos presentes na matriz gelatinosa do acérvulo, como também por conídios presentes nas setas férteis, sendo que o primeiro tipo de conídio só é disperso por respingos de chuva e o segundo tipo são dispersos pelo movimento do ar e podem alcançar maiores distâncias, portanto, sendo menor a velocidade do vento, há menor disseminação de conídios.

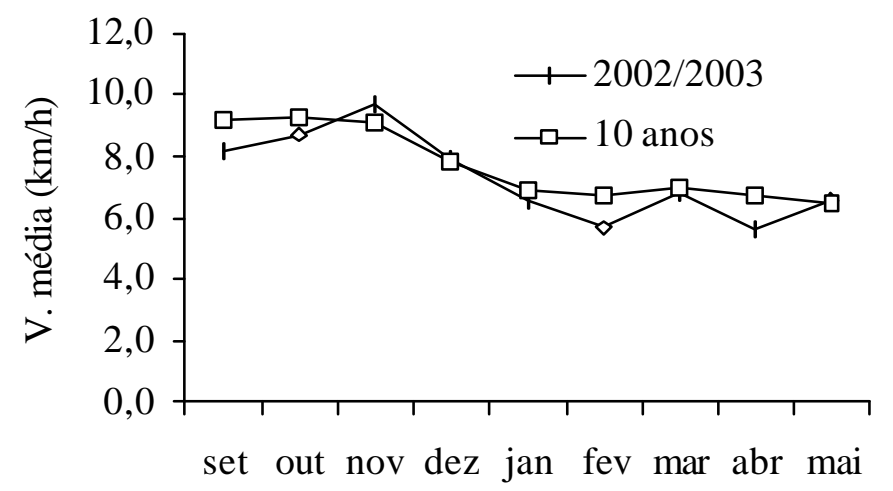

Figura 15- Comparação de medidas de Velocidade média do vento $(\mathrm{Km} / \mathrm{h})$ do período estudado em 2003/03 e dados médios de 10 anos. Piracicaba, SP 


\subsubsection{Insolação}

As médias das medidas de duração da insolação seguiram as tendências normais em quase todos os períodos ou meses (Figura 16), com uma pequena discrepância no mês de janeiro, quando a insolação foi menor, devido à períodos com tempo nublado, voltando a subir no mês de fevereiro, observando-se um incremento em relação à média normal para este mês.

Em relação à Ramulose, esta variável é importante, pois a insolação pode modificar a duração do período de molhamento foliar, afetando o processo infeccioso.

No mês de fevereiro, observa-se que a insolação esteve acima da média esperada para este mês, o que pode ter influenciado na duração do período de molhamento foliar (DPM), afetando o desenvolvimento da doença, principalmente na cultivar resistente.

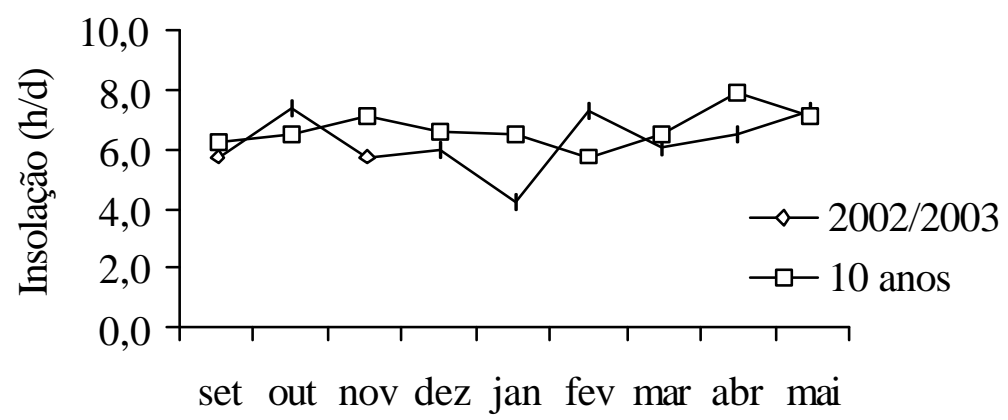

Figura. 16- Comparaçäo de medıdas de insolaçäo medıa (h/d) do periodo estudado em 2002/03 e dados médios de 10 anos. Piracicaba, SP 


\subsection{Produção de algodão em caroço e produtividade}

É possível observar na Tabela 12 que não houve interação entre os sistemas de semeadura e as cultivares utilizadas, indicando que a palhada não interferiu na produção das cultivares, porém, estes resultados se referem apenas à um ano de experimentação, não se podendo afirmar que nos anos seguintes os resultados sejam semelhantes. Os dois primeiros anos sob sistemas que utilizam palhada podem resultar em reduções na produtividade, como observaram Gassen \& Gassen (1996), provavelmente devido à imobilização dos nutrientes pelos microorganismos presentes na palhada e compactação do solo pelo não revolvimento, porém, estes resultados tendem a se alterarem a partir do terceiro ano sob o sistema.

Não houve diferença também de produção entre as duas cultivares (suscetível x resistente).

Tabela 12. Quadrado médio (Q.M.), F da análise de variância (F) e coeficiente de variação dos resíduos (C.V.) referentes à produção de algodão em caroço (kg). Ano agrícola 2002/03. Piracicaba, SP

\begin{tabular}{cccc}
\hline & \multicolumn{3}{c}{ Produção $(\mathrm{kg})$} \\
$\begin{array}{c}\text { Causas da } \\
\text { variacão }\end{array}$ & G.L. & Q.M. & $\mathrm{F}$ \\
\hline Bloco & 3 & 0,48 & 0,5 n.s. \\
Palhada (P) & 1 & 0,19 & 0,20 n.s. \\
Interação P x Bloco & 3 & 0,27 & 0,28 n.s. \\
Cultivar (C) & 1 & 0,004 & 0,00 n.s. \\
Interação (P) x (C) & 1 & 0,51 & 0,54 n.s. \\
Resíduo A & 22 & 0,95 & \\
Resíduo B & 3 & 0,27 & \\
C.V.\% & 27,89 & & \\
\hline
\end{tabular}

n.s. = não significativo a $5 \%$ de probabilidade, pelo teste $\mathrm{F}$ da análise de variância. 
Na Tabela 13 podem ser observadas as médias de produção de algodão em caroço e produtividade dos tratamentos. Houve diferença significativa entre os tratamentos inoculados e as testemunhas apenas em relação à doença, indicando que a Ramulose causou perda de produção de até $40 \%$, porém, esta avaliação não foi o objetivo do presente estudo, e em se tratando apenas dos tratamentos inoculados, podemos inferir que a palha não alterou a produção e produtividade da cultura.

Tabela 13. Médias da produção de algodão em caroço e da produtividade, em todos os tratamentos. Ano agrícola 2002/03. Piracicaba, SP

\begin{tabular}{ccc}
\hline Tratamentos & Produção & Produtividade \\
& Kg & Kg/ha \\
\hline Cultivar resistente, inoculada, com palha & $2,9963 \mathrm{bcd}$ & $1109,7 \mathrm{bcd}$ \\
Cultivar resistente, com palha, testemunha & $3,8673 \mathrm{abc}$ & $1432,3 \mathrm{abc}$ \\
Cultivar suscetível, inoculada, com palha & $2,9618 \mathrm{bcd}$ & $1096,9 \mathrm{bcd}$ \\
Cultivar suscetível, com palha, testemunha & $4,4850 \mathrm{a}$ & $1661,1 \mathrm{a}$ \\
Cultivar resistente, inoculada, sem palha & $2,7975 \mathrm{~cd}$ & $1036,1 \mathrm{~cd}$ \\
Cultivar resistente, sem palha, testemunha & $4,2855 \mathrm{a}$ & $1587,2 \mathrm{a}$ \\
Cultivar suscetível, inoculada, sem palha & $2,4753 \mathrm{~d}$ & $916,8 \mathrm{~d}$ \\
Cultivar suscetível, sem palha, testemunha & $4,1498 \mathrm{ab}$ & $1536,9 \mathrm{ab}$ \\
CV\% & 14,71 & 14,71
\end{tabular}

Os valores seguidos pela mesma letra na coluna não diferem estatisticamente, ao nível de 5\% de probabilidade, pelo teste de Tukey. 


\subsubsection{Caracteres agronômicos de laboratório}

Observando-se a Tabela 14 podemos inferir que não houve interação entre cultivar e o sistema de semeadura para os caracteres massa de 100 sementes, massa de um capulho e porcentagem de fibras. A diferença encontrada pode ser atribuída às características intrínsecas das cultivares, mostrando que a cultivar resistente IAC 23 possui maiores valores em relação à massa de 100 sementes e massa de um capulho em relação à cultivar suscetível Makina, que inversamente apresenta maiores índices de porcentagem de fibras.

Tabela 14. Média dos caracteres agronômicos de laboratório para os tratamentos Ano agrícola 2002/03. Piracicaba, SP

\begin{tabular}{cccc}
\hline Tratamento & \multicolumn{2}{c}{ Massa (g) } & Porcentagem \\
& 100 sementes & 1 capulho & de fibra \\
\hline Cultivar resistente, inoculada, com palha & $14,5 \mathrm{a}$ & $7,12 \mathrm{ab}$ & $37,02 \mathrm{~b}$ \\
Cultivar suscetível, inoculada com palha & $10,90 \mathrm{~b}$ & $6,07 \mathrm{c}$ & $41,68 \mathrm{a}$ \\
Cultivar resistente, inoculada, sem palha & $14,65 \mathrm{a}$ & $7,17 \mathrm{a}$ & $37,20 \mathrm{~b}$ \\
Cultivar suscetível, inoculada, sem palha & $11,52 \mathrm{~b}$ & $6,15 \mathrm{c}$ & $40,22 \mathrm{a}$ \\
CV\% & 3,82 & 4,55 & 1,64
\end{tabular}

Os valores seguidos pela mesma letra na coluna não diferem estatisticamente, ao nível de 5\% de probabilidade, pelo teste de Tukey. 
4.4 Características tecnológicas das fibras

Como pode ser observado na Tabela 15 , não houve interação entre o sistema de semeadura e a cultivar para as características comprimento, uniformidade de comprimento, micronaire, tenacidade e maturidade. Observa-se apenas diferença significativa para a uniformidade de comprimento entre as cultivares, sendo que a cultivar resistente IAC 23 apresenta índices superiores de uniformidade, em relação à cultivar suscetível Makina.

Tabela 15. Média das características tecnológicas das fibras para todos os tratamentos. Ano agrícola 2002/03. Piracicaba, SP

\begin{tabular}{|c|c|c|c|c|c|}
\hline Tratamento & $\begin{array}{c}\text { Comp. } \\
\text { Fibras } \\
\text { mm }\end{array}$ & Uniform. & Micronaire & Tenacidade & Maturidade \\
\hline $\begin{array}{l}\text { Cultivar resistente, } \\
\text { inoculada, com palha }\end{array}$ & $28,05 \mathrm{a}$ & $46,57 \mathrm{ab}$ & $4,42 \mathrm{a}$ & $28,30 \mathrm{a}$ & $78,5 \mathrm{a}$ \\
\hline $\begin{array}{l}\text { Cultivar suscetível, } \\
\text { inoculada, com palha }\end{array}$ & $28,10 \mathrm{a}$ & $44,92 \mathrm{~b}$ & $4,90 \mathrm{a}$ & $29,50 \mathrm{a}$ & $82,77 \mathrm{a}$ \\
\hline $\begin{array}{l}\text { Cultivar Resistente, } \\
\text { inoculada, sem palha }\end{array}$ & $27,90 \mathrm{a}$ & $47,90 \mathrm{a}$ & $4,42 \mathrm{a}$ & $28,97 \mathrm{a}$ & $79,55 \mathrm{a}$ \\
\hline $\begin{array}{l}\text { Cultivar suscetível, } \\
\text { inoculada, sem palha }\end{array}$ & $28,52 \mathrm{a}$ & $45,00 \mathrm{~b}$ & $4,77 \mathrm{a}$ & 29,67 a & $81,27 \mathrm{a}$ \\
\hline $\mathrm{CV} \%$ & 1,62 & 2,42 & 5,08 & 3,86 & 3,23 \\
\hline
\end{tabular}

Os valores seguidos pela mesma letra na coluna não diferem estatisticamente, ao nível de 5\% de probabilidade, pelo teste de Tukey. 


\section{CONCLUSÕES}

Sob as condições experimentais descritas, este primeiro ano de avaliações permitiu concluir que:

Quando as condições meteorológicas (sobretudo de temperatura e umidade relativa do ar) são favoráveis ao patógeno (Colletotrichum gossypii var cephalosporioides Costa), e a cultivar é suscetível, a presença da palha sobre a superfície do solo desfavorece o crescimento da doença;

Em condições meteorológicas não favoráveis ao patógeno, a cultivar resistente IAC 23 retoma o crescimento vegetativo. Na cultivar Makina, a doença cresce sob condições meteorológicas favoráveis e permanece estável sob condições meteorológicas desfavoráveis;

A presença da palha na superfície não influencia na produção e produtividade de algodão em caroço, nos caracteres agronômicos de laboratório e nas caracetísticas tecnológicas das fibras;

De um modo geral, quando as condições meteorológicas são normais ou típicas, o Sistema de Plantio Direto pode desfavorecer o desenvolvimento da Ramulose do algodoeiro devido à presença da palha na superfície, porém, em anos atípicos, a ocorrência da doença pode ser favorecida. 


\section{REFERÊNCIAS BIBLIOGRÁFICAS}

ABRAHÃO, J. Controle da Ramulose tardia do algodoeiro. O Biológico, v. 27, n. 6, p.121-123, 1961.

ADAMS, J. E. Influence of mulches on runoff, erosion and soil moisture depletion. Soil Science Society of America Proceedings, v.30, p110-114, 1966.

AGRIOS, G. N. Enviromental effects on disease development. In: AGRIOS, G. N. (Ed.) Plant Pathology. New York: Academic Press, 1997. p. 143-172.

ALLEN, S. J.; BROWN, J. F.; KOCHMAN, J. K. Effect of temperature, dew period, and light on the growth and development of Alternaria helianthi. Phytopathology, v. 73, p. 793-796, 1982.

AMORIM, L. Sobrevivência do inóculo. In: BERGAMIN FILHO, A.; KIMATI, H.; AMORIN, L. Manual de fitopatologia. São Paulo: Ceres, 1995. v.1, p.246-266.

ANUÁRIO BRASILEIRO DO ALGODÃO. Santa Cruz: Gazeta, 2003. 136 p.

ARMY, T. J.; WIESE, A. F.; HANKS, R. J. Effect of tillage and chemical weed control practices on soil moisture losses during the fallow period. Soil Science Society Proceedings, v. 1, p. 410-413, 1961. 
BATSON JUNIOR. W. E.; CACERES, J. Evaluation seegling disease control strategies for cotton planted in conventional and stale bed tillage systems. In: BELTWIDE COTTON CONFERENCE, Orlando, 2000. Proceedings. Memphis: National Cotton Council of América, 2000.

BEDENDO, I. P. Ambiente e doença. In: BERGAMIM FILHO, A.; KIMATI, H.; AMORIN, A. Manual de fitopatologia. 3. ed. São Paulo: Agronômica Ceres, 1995. v. 1, p. $331-341$.

BELTRÃO, N. E. M.; SOUZA, J. G. Fitologia do algodão herbáceo In: BELTRÃO, N. E. M.; BARRETO, A. N.; ,SILVA, C. A. D. O agronegócio do algodão no Brasil. Brasília: EMBRAPA, 1999. cap.3, p. 55-86.

BENOIT, G. R.; LINDSTROM, M. J. Interpreting tillage-residue management effects. Journal of Soil and Water Conservation., v. 1, p. 87-90, 1987.

BERGAMIN FILHO, A.; AMORIM, L. Doenças de plantas tropicais: epidemilogia e controle. São Paulo: Agronômica Ceres, 1996. 289p.

BROWN, E. A.; McCARTER, S. M. Effect of a seedling disease caused by Rhizoctonia solani on subsequent growth and yield of cotton. Phytopathology, v. 66, p.111$115,1976$.

CAPELLARI JUNIOR, L.; RODRIGUES, R.R.; SOUZA, V. C.; ROCHELLE, L.A. Botânica sistemática. Piracicaba: ESALQ, Departamento de Ciências Biológicas, 2002. 76p.

CARVALHO, L. P.; CAVARANTI, F. R.; LIMA, E. F.; SANTOS, E. O. Influência da Ramulose nas características de fibra e produção do algodoeiro. Fitopatologia Brasileira, v.2, n.23, p.593-598, out. 1984. 
CHIAVEGATO, E. J. Efeito do ambiente e de cultivares nos componentes da produção e nas características tecnológicas da fibra e do fio de algodão. Piracicaba, 1995. 115p. Tese (Doutorado) - Escola Superior de Agricultura "Luiz de Queiroz", Universidade de São Paulo.

CHIAVEGATO, E. J. Importância potencial de doenças do algodoeiro nas regiões produtoras do Brasil. In: CONGRESSO BRASILEIRO DE ALGODÃO, 3., Campo Grande, 2001.

CIA, E.; FUZATTO, M. G. Inspeção de campo visando sanidade de sementes de algodão. In: SIMPÓSIO BRASILEIRO DE PATOLOGIA DE SEMENTES, 2. Campinas, 1986. Resumos//Campinas: Fundação Cargill, 1986. p.49-56.

CIA, E.; SALGADO, C. L. Doenças do Algodoeiro. In: Manual de fitopatologia. São Paulo: Ceres, 1997. p. 33-48.

CIA, E.; FUZATTO, M. G. Manejo de doenças na cultura do algodão. In:CIA, E.; FREIRE, E. C.; SANTOS, W. J. (Ed.). Cultura do algodoeiro. Piracicaba: Potafós, 1999. p. 121-131.

CIA, E.; FUZATTO, M. G.; GRIDI-PAPP, I. L.; SOAVE, J.; CIONE, J. Avaliação da incidência de Ramulose do algodoeiro através de inoculação artificial. In: REUNIÃO NACIONAL DO ALGODÃO, 2., Salvador, 1982. Resumos. SALVADOR: Editora, 1982. p. 241. 
CIA, E.; GRIDI-PAPP, I. L.; CHIAVEGATO, E. J.; SABINO, N. P.; KONDO, J. I.; PIZZINATO, M. A.; BORTOLETO, N.; CARVAlHO, L. H. Melhoramento do algodoeiro no Estado de São Paulo: obtenção da cultivar IAC 21. Bragantia, v. 60, n. 1, p. 9-17, 2001.

DEUBER, R. Manejo integrado de plantas infestantes na cultura do algodoeiro.

In: Cultura do algodoeiro, Piracicaba: POTAFÓS, 1999. 286p.

FORTIN, M. C. Soil temperature, soil water, and no-till corn development following inrow residue removal. Agronomy Journal, v. 85, p. 571-576, 1993.

FOWLER, R.; ROCKSTROM, J. Conservation tillage for sustainable agriculture; Na agrarian revolution gathers momentum in Africa. Soil and Tillage Research, v. 61, p. $93-107,2001$.

GASSEN, D.; GASSEN, F. Plantio direto, o caminho do futuro. 2. ed. Passo Fundo: Aldeia Sul, 1996. cap. 1, p. 19-26: Teoria e princípios sobre plantio direto.

GRIDI-PAPP, I. L.; CIA, E.; FUZATTO, M. G. et al. Manual do produtor de algodão. São Paulo: BM \& F, 1992. cap. 8, p.89-101: Doenças.

GUPTA, S. C.; LARSON, W. E.; LINDEN, D. R. Tillage and surface residue effects on soil upper boundary temperatures. Soil Science Society of America Journal, v . 47, p.1212-1218, 1983.

GUPTA, S. C.; LARSON, W. E.; ALLMARAS, R.R. Predicting soil temperature and soil heat flux under different tillage-surface residue conditions. Soil Science Society of America Journal, v . 48, n. 2, p. 223-232, 1984. 
HAYMAN, D. S. The influence of temperature on the exudation of nutrients from cotton seeds and on preemergence damping-off by Rhizoctonia solani. Canadian Journal of Botany, v. 47, n. 3, p. 1663-1669, 1969.

HERNANI, L. C.; SALTON, J. C. Manejo e conservação do solo. Dourados: EMBRAPA, 1998. 267p.

HOSFORD, R. M.; LAREZ, C. R.; HAMMOND, J. J. Interaction of wet period and temperature on Pyrenophora tritici-repentis infection and development in wheats of differing resistance. Phytopathology, v. 77, n. 7, p. 1021-1027, 1987.

KAUFMAN, H. W.; WHEELER, T. A. et al. Conservation tillage practices in texas and their effects on seedling disease severity. In: BELTWIDE COTTON CONFERENCE, San Antonio, 1995. Proceedings. Memphis: National Cotton Council of America, 1995. p. 204.

KIMATI, H. Doenças do algodoeiro. In: GALLI, F. Manual de Fitopatologia. São Paulo: Ceres, 1980. v. 2, p. 29-48.

KLADIVKO, E. J.; VOORHEES, W. B. et al. Soil Change and residue and management. Soil and Tillage Research, v.61, n. 112, 2001. p. 61-76.

KRUGNER, T. L.; BACCHI, L. M. A. Fungos. In: BERGAMIN FILHO, A.; KIMATI, H.; AMORIN, L. Manual de fitopatologia. São Paulo: Ceres, 1995., v.1, p.46-95.

LENNÉ, J. M.; SONODA, R. M.; PARBERY, D. G. Production of conidia by setae of Colletotrichum species. Mycologia, v. 76, n. 2, p. 359-362, 1984. 
MACHADO, J. C. Padrões de tolerância de patógenos associados às sementes. In: LUZ, W. C. (Ed.). Revisão anual de patologia de plantas. Passo Fundo. v.2, p. 229-263, 1994.

MACHADO, J. C. Patologia de sementes: fundamentos e aplicações. Brasília: MEC, FAEPE, ESAL, 1988. 107 p.

MEDEIROS, G. B. O algodoeiro em sistema de plantio direto. In: COMGRESSO BRASILEIRO DE ALGODÃO 4., Goiânia, 2003. Minicurso plantio direto em algodão. Goiânia: 2003. p. 1-14.

MENTEN, J. O. M. Importância da semente na transmissão de patógenos. In: SIMPÓSIO BRASILEIRO DE PATOLOGIA DE SEMENTES, 2., Resumos, Campinas: Fundação Cargill, 1986. p. 27-40.

MENTEN, J. O. M. Situação dos padrões de sanidade de sementes. Summa Phytopathologica, v. 23, n. 1, p. 86-89, 1997.

MINISTÉRIO DA AGRICULTURA E REFORMA AGRÁRIA. Regras para análise de sementes. Brasília: SNDA; DNDV;CLAZ, 1992. 365p.

MONTEIRO, J. E. B. A. Microclima e ocorrência de Ramulose no algodoeiro em diferentes densidades populacionais. Piracicaba, 2002. 99p. Dissertação (Mestrado) - Escola Superior de Agricultura “Luiz de Queiroz”, Universidade de São Paulo.

NEERGAARD, P. Seed pathology. London: The Macmillan, 1997. 839p.

OOSTERHUIS, H. J. W. Growth and development of cotton plant In: CIA, E.; FREIRE, E. C.; SANTOS, W. J. Cultura do algodoeiro. Piracicaba: Potafós, 1999. p. 35-56. 
PAIVA, F. A.; ASMUS, G. L.; ARAÚJO, A. E. Doenças In: Algodão: tecnologia de produção. Dourados: Embrapa Agropecuária Oeste, 2001. p. 245-272.

PEDRO JUNIOR, M. J. Aspectos microclimáticos e epidemiologia. In: CURSO PRÁTICO INTERNACIONAL DE AGROMETEOROLOGIA PARA OTIMIZAÇÃO DA IRRIGAÇÃO, 3., Campinas, 1989. Resumos. Campinas: Instituto Agronômico, 1989. 13p.

PEREIRA, A. R., ANGElOCCI, L. R., SENTELHAS, P. C. Agrometeorologia, fundamentos e aplicações práticas. Guaíba: Agropecuária, 2002. 478p.

PIZZINATTO, M. A.; CIA, E.; FUZATTO, M. G. Relação entre a severidade de Ramulose do algodoeiro em condições de campo e a presença de Colletotrichum gossypii var. cephalosporioides nas sementes produzidas. Fitopatologia Brasileira. v.19, n.1, p. 50-54, 1994

REEVES, WAYNE. Sistemas de preparo conservacionista para algodão. In: ENCONTRO NACIONAL DE PLANTIO DIRETO NA PALHA. 7. Federação Brasileira de Plantio Direto na Palha. Foz do Iguaçu, PR. 2000. Encotro Nacional de Plantio Direto na Palha. Foz do Iguaçu. Resumos, Foz do Iguaçú, 2000. p.90-94.

ROTEM, J. Climatic and weather influences on epidemics. In: HORSFAL, J. G.; COWLING, E. B. (Ed.) Plant disease. An advanced treatise. New York: Academic Press, 1978. v. 2, p. 317-334.

ROTEM, J.; PALTI, J. Irrigation and plant disease. Annual Review of Phytopathology, v. 7, p. 267-288, 1969. 
SANTOS, G. R. Progresso da Ramulose do algodoeiro e transmissão de Colletotrichum gossypii South. var. cephalosporioides Costa pelas sementes. Viçosa, 1993. 53p. Dissertação (Mestrado). Universidade Federal de Viçosa.

SANTOS, G. R.; ZAMBOLIM, L.; BATISTA, U. G. Transmissão de Colletotrichum Gossypii var. cephalosporioides por sementes do algodoeiro em função do período de inoculação das plantas. Summa Phytopathologica. v. 19, n. 3, p. 177-180, 1993.

SANTOS, G. R.; ZAMBOLIM, L.; RIBEIRO, F. X.; MAFFIA, L. A.; VIEIRA, J. M. Progresso e gradiente da Ramulose do algodoeiro. Fitopatologia Brasileira. v.19, n. 3, p. 390-393. 1993.

SMART, J. R.; BRADFORD, J. M.; WOLFENBARGER, D. A. Cotton response to reduced tillage in the Lower Rio Grande Valley. In: BELTWIDE COTTON CONFERENCE, Orlando, 1995. Proceedings. Memphis: National Cotton Council of América, 1995.

SUMNER, D. R.; DOWLER, C. C.; JOHNSON, A.W.; BAKER, S. H. Conservation tillage and seedling diseases in cotton and soybean double-cropped with triticale. Plant Disease, v. 79, p.372-375, 1995.

SUTTON, J. C.; GILLESPIE, T. J.; HILDEBRAND, P. D. Monitoring weather factors in relation to plant disease. Plant Disease, v. 68, n. 1, p. 78-84, 1984.

VIANELLO, R. L.; ALVES, A. R. Meteorologia básica e aplicações. Viçosa: Impr. Univ., 1991. p.395-399. 
VON PINHO, R. G.; VON PINHO, E. V. R.; FRAGA, A. C.; MACHADO, J. C. Avaliação de fontes de resisitência à Ramulose causada por Colletotrichum gossypii var. cephalosporioides. Ciência e Agrotecnologia., v. 21, n.3, p.253-259, jul./set., 1997.

WANG, H.; DAVIS, R. M. Susceptibility of selected cotton cultivars to seedling disease pathogens and benefits of chemical seed treatments. Plant Disease, v. 81, n. 9, p.1085-1088, Mar. 1997.

WATKINS, G. M. Compendium of cotton diseases. St. Paul: APS, 1981. 87p.

YAMAOKA, R. S. Plantio direto do algodoeiro. In: CONGRESSO BRASILEIRO DE ALGODÃO. 2., Riberão Preto, 1999. Proceedings, Ribeirão Preto: Editora, 1999. p. $1-8$

YARWOOD, C. E. Humidity requeriments of foliage pathogens. Plant Disease Reporter, v.58, n. 2, p. 133-135, 1956.

YOUNG, J. Conservation tillage practices in Louisiana. In: BELTWIDE COTTON CONFERENCE, Orlando, 1995. Proceedings. Memphis: National Cotton Council of America, 1995. 1v. 